\title{
Foreign Banks in Poor Countries: \\ Theory and Evidence
}

\author{
Enrica Detragiache \\ International Monetary Fund \\ Poonam Gupta \\ Delhi School of Economics \\ Thierry Tressel \\ International Monetary Fund
}

Paper presented at the 7th Jacques Polak Annual Research Conference

Hosted by the International Monetary Fund

Washington, DC-November 9-10, 2006

The views expressed in this paper are those of the author(s) only, and the presence of them, or of links to them, on the IMF website does not imply that the IMF, its Executive Board, or its management endorses or shares the views expressed in the paper. 


\title{
Foreign Banks in Poor Countries: Theory and Evidence*
}

\author{
By Enrica Detragiache, Thierry Tressel, and Poonam Gupta
}

First draft: July 2005

Current draft: July 2006

\begin{abstract}
$\underline{\text { Abstract }}$
We study how foreign bank penetration affects financial sector development in poor countries. A theoretical model shows that when domestic banks are better than foreign banks at monitoring soft information customers, foreign bank entry may hurt these customers and worsen welfare. The model also predicts that credit to the private sector should be lower in countries with more foreign bank penetration, and that foreign banks should have a less risky loan portfolio. In the empirical section, we test these predictions for a sample of lower income countries and find support for the theoretical model.
\end{abstract}

JEL Classification Numbers: G21, O16

Keywords: Foreign banks; low income countries; banking

Author's E-Mail Address:Edetragiache@imf.org; Ttressel@imf.org; PGupta@imf.org;

* The views expressed in this paper are those of the author(s) and do not necessarily represent those of the IMF or IMF policy. The authors would like to thank Thorsten Beck, Simon Johnson, Sole Martinez Peria, Raghu Rajan, Arvind Subramanian, and participants to the joint World Bank/IMF Seminar for very helpful comments on an earlier draft. We are also greatly indebted to Ugo Panizza and Monica Yañez for sharing their data on bank ownership 


\section{Introduction}

A large theoretical and empirical literature argues that finance is good for growth (Levine, 1997; Beck and Levine, 2003). An implication of this work is that fostering the development of financial markets should help less developed countries lift themselves out of poverty. Indeed, estimates by Bekaert et al. (2005) indicate that financial liberalization, identified as the opening up the stock market to foreign investors, can increase the growth rate by as much as 1 percent per year. Recent work also suggests that financial development reduces inequality and poverty by disproportionately boosting the income of the poor (Beck, Demirgüç-Kunt and Levine, 2004).

Perhaps heeding the advice of economists, in recent years many poor countries have been a laboratory of financial sector reform. A rigorous evaluation of these efforts is still work in progress, but available accounts suggest that key deficiencies have been difficult to remove. ${ }^{1}$ This paper studies how one aspect of financial sector reform, the entry of foreign banks, affects financial sector development in poor countries.

Whether foreign bank entry is a help or a hindrance is the object of some contention among policy-makers and academics. ${ }^{2}$ Proponents of foreign banks claim that these banks can achieve better economies of scale and risk diversification than domestic banks, that they introduce more advanced technology (especially risk management), import better supervision

\footnotetext{
${ }^{1}$ Comprehensive descriptions of financial sector structure, performance, and soundness for several poor countries are provided in the Financial Sector Stability Assessments (FSSAs), jointly carried out by the World Bank and the IMF. Most of these reports are available at www.imf.org.

${ }^{2}$ For a summary of the issues, see, among others, International Monetary Fund (2000) and Agénor (2001). A more detailed literature review is in Section II of this paper.
} 
and regulation, and increase competition. Because they are backed by their parent banks, foreign affiliates of international banks may also be perceived as safer than private domestic banks, especially in times of economic difficulties. Last but not least, foreign banks may be less susceptible to political pressures and less inclined to lend to connected parties. These forces imply a positive relationship between foreign bank presence and indicators of financial sector performance.

Despite these advantages, critics point out that an important part of a bank's business, namely lending to informationally opaque firms, is inherently local in nature, and is not easily carried out by large organizations managed from afar. In fact, evidence from bank consolidation in advanced countries suggests that large banks are less prone than small bank to lend to informationally difficult firms, such as small firms, because there is a greater distance between loan officers and management (Berger et al., 2005). ${ }^{3}$ Using Italian data, Guiso et al. (2004) find that local financial development matters to firms creation and growth even when there are no barriers to cross-regional financial flows, as entrepreneurs find it difficult to fund themselves from institutions located at a geographical distance.

In the case of foreign banks operating in poor countries, the distance (both geographic and cultural) between headquarters and local subsidiaries is likely to be especially large. In addition, many, if not most, potential borrowers lack usable collateral and reliable accounting information, and are therefore informationally difficult. Thus, the problems highlighted by

\footnotetext{
${ }^{3}$ Black and Strahan (2002) show that deregulation of interstate banking and branching in the U.S. had a favorable impact on firm creation, as it led to more competition and consolidation. They argue that the risk diversification benefits of bank size more than offset the disadvantages in forging relationships.
} 
studies of bank consolidation in advanced countries may be compounded when foreign banks operate in poor countries. Consistent with this view, several studies find that foreign banks in poor countries lend predominantly to the safer and more transparent customers, such as multinational corporations, large domestic firms, or the government. ${ }^{4}$ Even when foreign banks enter by purchasing local banks, local market knowledge and relationships with customers may be lost, as distant managers need to impose formal accountability to monitor local loan officers. In fact, evidence from advanced countries indicates that, when a bank is acquired by another bank, the bank-firm relationships of the target bank are disrupted (Sapienza, 2002; Carow et al., 2004; Karceski et al., 2004; Degryse et al., 2004).

From a public policy perspective, however, it is not clear that foreign banks' focus on high-end customers should be a concern. As long as domestic banks continue to lend to more opaque but profitable customers, there should be no welfare loss, and foreign bank entry may simply result in a welfare-improving segmentation of the market. On the other hand, if foreign bank entry forces domestic banks out of the market, then more opaque firms may become credit constrained, aggregate credit may decline, and profitable investment opportunities may be lost. In this paper, we explore these questions both theoretically and empirically.

In our theoretical model, foreign banks are better than domestic banks at monitoring "hard" information, such as accounting information or collateral values, but not at monitoring "soft" information, such as the borrower's entrepreneurial ability or trustworthiness. In this

\footnotetext{
${ }^{4}$ See Bonin and Wachtel (2003) on Eastern Europe, Brownbridge and Harvey (1998) on Anglophone Africa, Mian (forthcoming) for Pakistan, Haber and Musacchio (2005) for Mexico, Clarke et al. (2005) for Latin America, and Gormley (2005) for India.
} 
set up, in some parameter configurations foreign bank entry increases cost efficiency and welfare, while in others it leads to a reduction in overall lending, efficiency, and welfare. The intuition for the latter - more surprising - result is that foreign bank entry causes "creamskimming," whereby hard information borrowers are no longer pooled with other borrowers. This has two consequences: first, soft information borrowers find themselves in a worse pool (because the "cream" has been "skimmed"), and have to pay such high interest rates that they may no longer want to borrow. Second, monitoring costs are paid in equilibrium, which increases operating costs. Welfare may increase or decrease depending on the parameters, but soft information borrowers are never better off and sometimes they are worse off.

The model has two clear empirical implication: first, across countries a larger foreign bank presence is associated with less credit to the private sector; and second, within any given country domestic banks have a riskier loan portfolio than foreign banks. In the second part of the paper we test these predictions for a sample of lower income countries. Using country-level data, we find that countries with a larger foreign bank presence have shallower credit markets in poor countries, as implied by the model. This effect is large, robust to the choice of specification, and it holds both in a cross-sectional and dynamic panel specification. In addition, credit growth is slower in countries with a larger initial foreign bank presence. The relationship also holds when we instrument the foreign share to control for endogeneity.

In a second empirical test, we show that in poor countries loan loss provisions and loan loss reserves are higher in domestic banks than in foreign banks after controlling for bank characteristics and country-time fixed effects. These findings are consistent with the predictions of the cream-skimming model. 
In additional tests, we show that foreign bank presence is negatively associated with indicators of access to financial services, such as branch penetration and number of deposits per capita. We interpret these results as supporting the view that the entry of foreign banks in poor countries leads to "cream skimming" and a decline in credit to opaque firms. The empirical relationship between foreign bank presence and financial performance becomes statistically insignificant when we include higher income countries in the sample. This is consistent with the theoretical model, because differences in monitoring abilities between foreign and domestic banks are likely to be less marked in these countries. This finding underscores the need to allow for heterogeneity among groups of countries of different income level when studying the effects of financial reforms.

The paper is organized as follows: The next section reviews the empirical literature on foreign banks in poor countries. Section III presents the theoretical model and derives testable implications. Section IV discusses the empirical methodology and data. Section V presents the results of the empirical tests. Section VI concludes.

\section{Empirical Evidence on Foreign Banks in Poor Countries}

A number of empirical studies have investigated various implications of the increased globalization of banking in general, and of growing foreign bank presence in developing countries in particular. The evidence is drawn both from cross-country samples and individual country studies.

Based on cross-country studies, foreign-owned banks have been found to have lower operating costs and higher profitability than private domestic banks, while state-owned banks have higher costs and lower profitability than the other two categories (Mian, 2003; Micco, 
Panizza, and Yañez, 2004). Foreign bank entry in developing countries also appears to lower interest margins and profitability, suggesting an increase in competition (Claessens, Demirgüç-Kunt, and Huizinga, 2001; Gelos and Roldós, 2004; Micco, Panizza and Yañez, 2004; Martinez-Peria and Mody, 2004). A recent study of eight Latin American countries, however, finds the opposite to be true (Levy-Yeyati and Micco, 2003).

Turning to the effects of foreign bank entry on access to credit, surveys of entrepreneurs indicate that firms are less credit-constrained in countries with more foreign bank participation (Clarke et a., 2004). On the other hand, a study of lending behavior in four Latin American countries concludes that foreign banks lend less to SMEs than domestic banks on average, although this is not true for foreign banks that have a large presence in the country (Clarke et al., 2005). In Eastern Europe, Giannetti and Ongena (2005) find that foreign bank presence benefits all firms, though the effects are more pronounced for large firms and firms less likely to be involved in connected lending.

Additional evidence on foreign and domestic bank behavior in LDCs comes from individual country studies. Haber and Musacchio (2005) analyze Mexico's experience in the 1990s. After a mismanaged bank privatization led to a financial crisis in 1994-95, the Mexican government introduced several reforms, including liberalization of foreign bank entry. As the presence of foreign banks grew, bank capitalization improved and NPLs and operational expenses declined, but lending, particularly to the private sector, declined. The fall in private lending was more pronounced in foreign than in domestic banks. Thus, while the Mexican banking system has become more stable and profitable, it seems to have retreated from the business of lending to the private sector. Haber and Musacchio's view is that deep reforms to improve the enforcement of property rights are necessary to enable 
financial intermediation, and especially lending by foreign banks, to reach risky borrowers in Mexico.

Drawing on an exceptionally rich dataset of 80,000 business loans in Pakistan, Mian (2006) finds that private domestic banks lend more to informationally opaque businesses than foreign banks, and that they are more successful at recovering defaulted debt. The interpretation of these results is that distance constraints (both cultural and geographic) between top management and loan officers force foreign banks to curtail discretion in lending decisions, resulting in less lending to informationally opaque smaller businesses, as in the theoretical model of Stein (2002). Distance also appears to impair the recovery of defaulted loans.

In a third country study on India, Gormley (2005) compares borrowing behavior of firms located in districts with and without foreign bank entry. He concludes that the 10 percent most profitable firms benefited from foreign bank entry through an increase in loan size, while other firms experienced a 7.6 percent drop in their likelihood of having a loan. This result is driven by a decrease in domestic bank loans to group-affiliated firms. The result holds after instrumentation of foreign bank location. ${ }^{5}$

In the next section, we develop a simple theoretical model to explore how entry by banks more skilled at lending to high quality, less opaque customers may affect the credit market equilibrium and welfare.

\footnotetext{
${ }^{5}$ Gormley also presents a theoretical model in which foreign banks have higher monitoring costs but lower funding costs than domestic banks. In this model foreign bank entry can result in less credit being made available to creditworthy but lower quality borrowers.
} 


\section{Cream-Skimming Effects of Foreign Bank Entry: Theory}

In a world of perfectly competitive markets and full information, foreign bank entry in poor countries should undoubtedly be welfare improving. With access to better technology, more opportunities to diversify risk, and, possibly, better corporate governance, these banks should be able to offer more attractive interest rates and increase the volume of credit. When information about borrower quality is imperfect, on the other hand, banks have to screen and monitor perspective borrowers. If foreign banks have an advantage only in lending to the less opaque customers, the effects of foreign bank entry on credit availability, efficiency, and welfare are not clear cut. In this section, we develop a theoretical model to shed light on this issue. The model is a simple variant of the standard credit market model with adverse selection.

\section{The model with only domestic banks}

There are two categories of agents, banks and entrepreneurs, and two time periods. Banks are perfectly competitive. They have access to a perfectly elastic supply of funds and their cost of funds is normalized to one. Entrepreneurs are risk-neutral and are one of three types $\theta \in\{H, S, B\}$ randomly assigned in the first period. The proportion of each type of entrepreneurs is given by $\mu \in\left\{\mu_{H}, \mu_{S}, \mu_{B}\right\}$, where $\mu_{H}+\mu_{S}+\mu_{B}=1$. Each entrepreneur knows his type, but other market participants do not; he has no private resources and must obtain financing from a bank. ${ }^{6}$ Banks can raise unlimited funds. Individuals of type $B$ (the

\footnotetext{
${ }^{6}$ The model could easily be enriched by adding moral hazard and collateral constraints. The main conclusions would hold or even be reinforced.
} 
bad borrowers) have access to a risky project which requires an initial investment of one unit and returns $R>1$ units with probability $p$ in period two. The project is assumed to have negative net present value, i.e. $p R<1$, but limited liability makes it an attractive "gamble", so if $B$ types receive financing they invest. Entrepreneurs of type $H$ and $S$ have access to an identical, safe, socially efficient project requiring an initial investment of size $I=1$ and returning $R>1$ in period two with probability one.

Two monitoring technologies allow banks to identify the type of an agent ex ante. Through the first technology, which costs $c_{H}$ per project, banks monitor hard information, such as balance sheets prepared according to transparent accounting standards or assets that can be used as collateral. Based on this information, banks can perfectly identify agents of type $H$, but cannot separate out type $S$ entrepreneurs from types $B$. To identify type $S$ entrepreneurs, banks must monitor soft information, such as the person's entrepreneurial skills and honesty. The soft information technology $\operatorname{costs} c_{S}$ per project. We assume that monitoring soft information is more costly than monitoring hard information $\left(c_{S}>c_{H}\right)$.

At the beginning of the first period, banks offer potential customers a menu of contracts consisting of one or more interest rate/monitoring strategy combination. For instance, a bank may offer an interest rate with no monitoring, another interest rate with monitoring of the applicant's hard information, and a third interest rate with monitoring of the applicant's soft information. Perspective borrowers choose one of the contracts on offer or decline to borrow. 
In this set-up, there are four possible equilibrium outcomes. Consider first the pooling outcome (equilibrium A), in which banks offer a contract involving no monitoring and all firms accept it. For banks to break even under pooling, they must charge an interest factor $r_{P}$ such that:

$$
r_{P}=\frac{1}{\mu_{H}+\mu_{S}+p \mu_{B}}=\frac{1}{p+(1-p)\left(\mu_{H}+\mu_{S}\right)}
$$

For all entrepreneurs to accept the pooling contract, the return from the project must be large enough to cover the pooling rate $\left(\mathrm{R}>r_{P}\right)$ and there must not be a more attractive interest rate on offer. ${ }^{7}$ Since monitoring hard information is cheaper than monitoring soft information, a sufficient condition is that the break-even interest factor $r_{H}$ that a bank has to charge when monitoring hard information exceed the pooling rate, i.e.

$$
r_{H}=1+c_{H}>r_{P}
$$

This condition holds if the cost of monitoring hard information is large relative to the potential loss from lending to bad borrowers.

Suppose this condition fails to hold so pooling is not an equilibrium outcome. Then banks can attract type $H$ agents by offering to monitor hard information and charging the interest factor $r_{H}$. If $H$ types sort themselves out, banks can either monitor soft information and lend to agents of type $S$ (equilibrium B) or they can choose not to monitor and pool $S$ and $B$ types together (equilibrium $C$ ). A third possible outcome occurs if the return on the

\footnotetext{
${ }^{7}$ We are assuming that banks can commit to monitor even when they know that only a certain type of borrower will approach them in equilibrium, and hence monitoring is not necessary ex post.
} 
project $\mathrm{R}$ is not sufficient to cover the cost of monitoring soft information or the cost of adverse selection (i.e., the cost to $\mathrm{S}$ types of pooling with $\mathrm{B}$ types). In this case, only $H$ types receive credit (equilibrium D).

Monitoring soft information strictly dominates pooling S types and B types together if and only if $r_{S}=1+c_{S}<\hat{r}_{P}$, where $\hat{r}_{P}$ is the break-even interest factor when the $\mathrm{S}$ and $\mathrm{B}$ types are pooled together, i.e.:

$$
\hat{r}_{P}=\frac{1}{\frac{\mu_{S}}{\mu_{S}+\mu_{H}}+p \frac{\mu_{B}}{\mu_{S}+\mu_{H}}}=\frac{1}{p+(1-p) \frac{\mu_{S}}{\left(1-\mu_{H}\right)}} .
$$

Note that $r_{P}$, the pooling interest factor, is always lower than $\hat{r}_{P}$, because when $H$ types are monitored and drop out of the pool, banks face a worse pool of borrowers. ${ }^{8}$ With these results in hand, it is straightforward to derive the following proposition:

\section{Proposition 1:}

(A) (pooling equilibrium): If $R>r_{P}$ and $r_{H}>r_{P}$, then the equilibrium is pooling. All projects are funded, and no monitoring costs are paid.

(B) (separating equilibrium): If $r_{H}<r_{P}, r_{S}<\hat{r}_{P}$, and $r_{S}<R$, then the equilibrium is separating. Banks monitor both hard information and soft information and lend to H types and $S$ types. B types do not receive any credit.

\footnotetext{
${ }^{8}$ To show that $\hat{r}_{P}>r_{P}$ it is sufficient to show that $\mu_{H}+\mu_{S}>\frac{\mu_{S}}{1-\mu_{H}}$, which is always the case since $1-\mu_{S}-\mu_{H}<1$.
} 
(C)(semi-pooling equilibrium): If $r_{H}<r_{P}, r_{S}>\hat{r}_{P}$, and $r_{S}<R$, then the equilibrium is semipooling. Banks monitor hard information only. H types borrow at interest factor $r_{H} ; S$ and $B$ types are pooled together and borrow at interest factor $\hat{r}_{P}$.

(D) (credit-constrained equilibrium): If $r_{H}<r_{P}, R>r_{H}$, and $R<\min \left[\mathrm{r}_{\mathrm{S}}, \hat{r}^{p}\right]$, then in equilibrium banks monitor hard information and lend to $H$ types, while $S$ and $B$ types do not receive any credit.

\section{The model with domestic and foreign banks}

Consider now a model in which both domestic and foreign banks compete. Foreign banks are assumed to have a lower cost of monitoring hard information but a higher cost of monitoring soft information than domestic banks. Let $c_{H}-\Delta$ and $c_{s}+\Delta^{\prime}$ denote monitoring costs for foreign banks, with $\Delta>0$ and $\Delta^{\prime}>0 .{ }^{9}$ This assumption is consistent with the findings in Mian (2005) that foreign banks lend disproportionately to hard information borrowers relative to domestic banks. Anecdotal evidence from Mexico also suggests that foreign banks can better screen hard information than domestic banks. ${ }^{10}$ Similar results could be obtained by assuming that foreign banks have the same costs of monitoring hard

\footnotetext{
${ }^{9}$ To keep things simple, we will assume that, when indifferent, borrowers choose to borrow from domestic banks. This assumption can be rationalized by the presence of small entry costs for foreign banks.

${ }^{10}$ In 2004, investments in technology allowed Scotiabank Inverlat to approve car loans electronically in two hours, down from four days in 2000. Processing time for mortgage loans was reduced from seven working days to four hours (The Globe and Mail, 16 October 2004, p. B4, quoted in Schulz, 2006). The assumption that foreign banks have higher cost of monitoring soft information than domestic banks is needed to ensure that domestic banks do some lending in equilibrium.
} 
information as domestic banks but have a lower cost of funding. As long as the cost-of-fund differential between domestic and foreign banks is smaller than the differential in the cost of monitoring soft information, then the same equilibrium outcomes would obtain.

In the version of the model with foreign and domestic banks, it is straightforward to see that the results of Proposition 1 continue to hold, except that in the definition of $r_{H}$-the interest factor bank offer when monitoring hard information $-c_{H}$ should be replaced by $c_{H}-\Delta$, the lowest cost of monitoring hard information available on the market. Accordingly, other things being equal, the pooling equilibrium becomes less likely when foreign banks are present, as hard information firms are more likely to sort themselves out. If the equilibrium with domestic banks only is not pooling, the regions of the parameters in which the other three outcomes arise do not change, because they do not depend on $c_{H}$.

Let us consider the allocation of lending between domestic and foreign banks in the various equilibrium outcomes. If the equilibrium is pooling, no monitoring takes place and the better monitoring skills of foreign banks are immaterial. Accordingly, firms borrow only from domestic banks. In the other equilibrium outcomes, on the other hand, foreign banks lend to hard information firms, since they can offer them more attractive terms than domestic banks. Domestic banks lend to soft information firms only (in the separating and credit constrained outcomes) or to both soft information and bad firms (in the semi-pooling outcome).

\section{Testable Implications}


Obtaining testable implications from the cream-skimming model is complicated by the fact that the equilibrium can be of four different types depending on the values of the parameters. Because many of the parameters (for instance, the proportions of the various types of borrower in the market) are not directly observable, we cannot determine in which type of equilibrium a particular banking system is at any given time. Our strategy to identify testable implications is to look for predictions for observable variables that are independent of the type of equilibrium.

Table 1 summarizes the values of some observable endogenous variables in the four possible equilibria. Consider first the relationship between and the ratio of bank credit to output and foreign bank penetration (lines three and four, Table 1). Moving from pooling to semi-pooling, separating, and the credit-constrained equilibrium, foreign bank penetration gradually increases. The ratio of credit to output remains constant in the semi-pooling equilibrium, but then declines in the separating and credit-constrained equilibrium. Hence, in a sample that contains countries in all types of equilibria, we would expect to find a negative correlation between foreign bank penetration and the ratio of credit to GDP.

Next, consider differences in cost efficiency between foreign and domestic banks: in the semi-pooling equilibrium domestic banks do not pay monitoring costs while foreign banks do, so domestic banks have lower overhead costs. On the other hand, in the separating equilibrium both types of banks pay monitoring costs, but the cost of monitoring hard information (paid by foreign banks) is lower than the cost of monitoring soft information 
(paid by domestic banks). So the model does not provide clear cut implications for differences in cost efficiency between foreign and domestic banks. ${ }^{11}$

Consider now loan losses. Foreign banks only lend to hard information borrowers who never default, so loan losses are always zero. On the other hand, in some equilibria domestic banks lend also to bad borrowers, and a fraction (1-p) of these borrowers defaults ex post. Hence, a testable implication of the cream-skimming model is that, in a sample rich enough to include countries in various types of equilibria, foreign banks should have a safer loan portfolio than domestic banks. ${ }^{12}$ Another implication of the model is that banking sectors with more foreign banks should have, on average, smaller loan losses. Because rules on loan classification and provisioning vary widely across countries, however, international comparisons of accounting measures of loan losses have little meaning, and we do not explore this testable implication.

It is interesting to note that an alternative model, in which foreign banks have a better loan portfolio because of a technological advantage in risk management, would yield the opposite prediction as to the relationship between foreign bank penetration and private credit than the cream-skimming model: better risk management should lead to a deepening of the credit market, not a shallowing. So testing both the prediction on loan losses and that on total credit should allow us to differentiate among the two models.

\footnotetext{
${ }^{11}$ It can also be easily shown that the model yields ambiguous implications about the relationship between average cost efficiency in the banking system and foreign bank penetration. In an earlier version of this paper we found an insignificant relationship between these two variables in cross-country regressions.
} 


\section{Welfare effects of foreign bank entry}

Before turning to the empirical tests, it is interesting to consider the welfare implications of the cream-skimming model. Because of adverse selection, the equilibrium is never first best optimal. Does foreign bank entry reduce the distortion and improve welfare? Do the gains accrue to all borrowers?

Our definition of welfare is aggregate output net of investment and monitoring costs. Consider first the case in which the initial equilibrium is one of the outcomes in which banks monitor hard information, i.e. one of the non-pooling outcomes. With foreign bank entry, the cost of monitoring hard information falls, making pooling even less attractive for $\mathrm{H}$ types. So the equilibrium continues to be non-pooling. Can the equilibrium type change (for instance from separating to semi-pooling)? The answer is no. Once pooling is ruled out, the nature of the equilibrium does not depend on the parameter $c_{H}$, so if the initial equilibrium is separating it will continue to be separating, and similarly for the other possible outcomes (see Proposition 1). The equilibrium payoff to B and $\mathrm{S}$ types is unchanged, while $\mathrm{H}$ types are better off because they pay lower interest rates. So, if the parameters are such that the initial equilibrium is not pooling, foreign bank entry is welfare increasing, but all the gains are appropriated by the less opaque borrowers on the market.

Consider now the case in which the initial equilibrium is pooling. If the cost of monitoring $\mathrm{H}$ is much lower, then pooling no longer is an equilibrium after foreign bank entry. When the cost of monitoring soft information is relatively low, entry by foreign banks causes the economy to move to the separating equilibrium B. This is depicted in the first 
panel of Figure 1. As a result, type $B$ agents no longer get credit and aggregate lending falls. The overall welfare impact, however, is ambiguous (see Appendix 1), because while it is efficient not to lend to type $B$ individuals, this comes at the cost of monitoring the other types. The reason why a decline in welfare is possible is that type $H$ agents choose to be monitored whenever monitoring costs are less than the subsidy to type $B$ agents that they pay via a higher cost of capital. But the social cost of switching away from the pooling to the separating equilibrium also includes the cost of monitoring $S$ types and the rents earned by $B$ types when their project succeeds. Thus, the transition from equilibrium A to equilibrium B that occurs for $c_{H}=r_{P}-1$ is socially optimal only for some parameter values, specifically for a large enough decline in the cost of monitoring hard information.

If the cost of monitoring soft information is relatively large while the cost of adverse selection is small, then the economy moves to the semi-pooling equilibrium $\mathrm{C}$, in which it is not profitable for banks to separate between type $B$ and type $S$ agents. In this case, all agents continue to receive credit, so aggregate credit does not change. However, it is easy to see that welfare unambiguously declines, because the inefficient investment projects of type $B$ agents are still financed while additional resources are spent on monitoring costs (see second panel in Figure 1).

Finally, if the cost of monitoring soft information and the cost of adverse selection are both large relative to the return from the project, the economy moves to the creditconstrained equilibrium $\mathrm{D}$, in which total lending falls because both $S$ and $B$ types are unable to borrow. The welfare impact is again ambiguous, as the benefit of not financing $B$ types has to be set against the increased cost of monitoring $H$ types and the cost of losing the project of 
the $S$ types. Again, one can show that the transition between the pooling equilibrium $\mathrm{A}$ and the credit-constrained equilibrium D will occur at a monitoring $\operatorname{cost} c_{H}$ that is too high from the point of view of social efficiency, and welfare may decrease (shaded area of Figure 1).

To sum up, entry by foreign banks has ambiguous welfare effects. However, the distributional consequences are clear: hard information borrowers are always either indifferent or better off, while other borrowers are always either indifferent or worse off.

\section{Relationship with the theoretical literature}

The result that costly screening or signaling can lead to welfare losses is not new. In many situations screening does not have any social returns and is simply a costly device to redistribute output across agents. For instance, Arrow (1973) argued that high education can help identify more productive individuals, but can decrease welfare if it does not improve the productivity of workers.

Cream-skimming is a well-known problem in insurance markets. For example, Lewis and Sappington (1995) show that if some agents are well informed about their risk characteristics, there is less insurance available in the market. More specifically, in their model some agents have perfect information about their final wealth, and the optimal insurance policy against wealth shocks provides full insurance for the smallest and the largest wealth realizations, but no insurance for a range of intermediate wealth realizations.

Another channel through which foreign bank entry may affect aggregate credit, which we do not explore in this paper, is through its effects on relationship banking. In relationship banking, banks learn agents' type through repeated interactions. However, relationships are 
more likely to be sustained in markets in which competition is relatively limited, so that banks can enjoy ex-post rents. Consistent with this argument, Petersen and Rajan (1994) find that the availability of credit to small businesses increases as competition in the banking sector declines. Similarly, increased competition from foreign bank entry may erode incentives to establish long-term relationships, reducing aggregate lending. ${ }^{13}$

\section{The Empirical Test: Methodology and Data}

\section{Sample}

Since our focus is on poor countries, we restrict our analysis to the countries defined by the World Bank as low income and lower middle income (Table A1). ${ }^{14}$ This group is large and heterogeneous, both geographically and in terms of income per capita. It includes the poorest countries in the world as well as a few relatively sophisticated emerging markets, such as Russia and Brazil. The total number of countries is 89 , but the sample used in the regressions is smaller and varies somewhat across specifications depending on data availability. In the country-level regressions, four countries (China P.R., Jordan, Eritrea, and Thailand) are excluded because they are outliers with respect to private credit. We also consider alternative samples including higher income countries.

${ }^{13}$ Dell'Ariccia and Marquez (2004), however, reach the opposite conclusion in a theoretical model in which, when faced with greater competition from new lenders with access to cheaper funds, domestic banks respond by reallocating credit toward more "captured" borrowers, i.e. borrowers with whom they have a long-term relationship. In this model, all borrowers benefit from foreign bank entry.

${ }^{14}$ As customary, we exclude very small countries, defined as countries with a population of less than one million. 


\section{Identifying Bank Ownership}

To identify bank ownership we use data constructed by Micco, Panizza, and Yañez (2004) from the Bankscope database for the period 1995-2002. Bankscope contains an ownership code that classifies banks as state-owned, private domestic, and foreign, but the code is available only for a subset of banks and it refers only to the last year in the database. Bankscope also provides some historical information about banks, including changes in ownership, but the information is not exhaustive. Micco, Panizza, and Yañez have constructed a time-series of bank ownership combining Bankscope information with individual bank information from outside sources for the years 1995 to 2002. A bank is classified as foreign if at least 50 percent of its capital is in the hands of non-residents.

The share of foreign bank assets to total bank asset in each country used in the country-level regressions is computed aggregating individual bank information. A limitation of our data is that coverage of Bankscope changes over time, so it is possible that changes in measured foreign bank penetration reflect changes in coverage. Most of the changes in coverage reflect broadening coverage over time. To the extent that broadening coverage does not disproportionately affect banks of different ownership, then our measure of foreign bank penetration should be accurate. Even if there is measurement error, because perhaps coverage of domestic banks improves over time but coverage of foreign banks does not, we would still have no bias as long as the error does not systematically differ for countries with different growth rates of aggregate private credit. We have no reason to believe this to be the case. In any case, this limitation only affects panel regressions using aggregate data, while crosscountry aggregate regressions and bank level regressions are not affected. 


\section{Country-Level Regressions}

The dependent variable is the volume of credit, measured as the ratio of commercial bank credit to the private sector to GDP from the International Financial Statistics of the IMF. ${ }^{15}$ In the cross-sectional regressions, the variable is computed as the average of the last three years of data available (1999-2002) to smooth out business cycle effects.

To limit joint endogeneity concerns, in the cross-sectional regressions we measure foreign bank presence at the earliest possible date. The Micco, Panizza, and Yañez (2004) dataset starts in 1995 for most countries, but for some we only have data for later years. To maximize sample size, we include also countries for which foreign bank presence is available in 1996, 1997, or 1998. An alternative measure of foreign bank presence drawn from a survey of bank supervisors is available from Barth et al. (2001). However, this variable refers to the period 1998-1999, so we use this measure for robustness tests rather than in the main specification.

Economic theory and existing empirical research point to a very broad set of potential determinants of financial sector performance, so selecting a benchmark specification is difficult. Our approach is to include variables that capture several basic country characteristics and then conduct extensive sensitivity analysis to verify the robustness of the coefficient of the foreign bank to the set of included controls.

\footnotetext{
${ }^{15}$ We only use private credit data for deposit money banks (IFS line 22d) rather than the sum of lines $22 \mathrm{~d}$ and $42 \mathrm{~d}$ (which refers to other financial institutions), as is done in other studies. Line $42 \mathrm{~d}$ is available only for a subset of countries, and setting it equal to zero for missing countries obviously misstates cross-country differences in depth.
} 
The first control variable is the overall level of development in the country measured by GDP per capita. ${ }^{16}$ A dummy for countries that made the transition to a market economy is also introduced as a control, as these countries encountered unique obstacles in creating a market-based financial system after decades of central planning. ${ }^{17}$ Inflation has also been found to correlate with measures of financial depth in broad samples of countries (Boyd, Levine, and Smith, 2001), so we use it as a control variable. An unstable and corrupt political system is also likely to be a deterrent to financial development, as it may bring about macroeconomic instability, increase the cost of doing business, and create uncertainty about property rights. Civil strife and outright war can destroy capital and infrastructure. Expropriation may follow revolutions or coups d'etat. We experimented with various measures of political stability, internal conflict, military control of the government, and freedom from corruption, and found the latter to be most strongly correlated with financial performance. So we include freedom from corruption as a regressor in the benchmark specification. $^{18}$

It is widely acknowledged that "market infrastructure" is important to financial sector performance. The Doing Business database by the World Bank provides a comprehensive

\footnotetext{
${ }^{16}$ The empirical relationship between financial depth and the level of development was first documented by Goldsmith (1969).

${ }^{17}$ Some of the more advanced transition countries which are not low income or lower-middle income countries, so they are excluded from our sample. For an overview of financial sector issues in transition economies, see Bonin and Wachtel (2003) and De Nicolo' et al. (2003).

${ }^{18}$ It might be argued that more corruption might result in more lending if loans are used as instruments to allocate favors to connected parties. Even though our sample of countries has a fairly high average level of corruption, we find that more corruption is associated with less, not more, private credit.
} 
new set of measures of administrative and regulatory obstacles to business activity for a large group of countries. One advantage of these indicators is that they directly measure quantifiable aspects of the business environment, rather than reflecting broad judgments by market participants. Some of the indicators are directly related to banking, as they measure aspects such as the cost of establishing collateral and recovering defaulted loans, and the availability of information on potential borrowers (through credit registries and other sources). Among these indicators, the more robust correlates of private credit are an index of the availability of information to creditors and the time it takes to enforce contracts. ${ }^{19} \mathrm{We}$ use these two variables as controls in the benchmark regression.

We estimate several versions of the following basic cross-sectional equation:

$$
y_{i}=\alpha+\beta f_{i}+\gamma \mathbf{X}_{\mathbf{i}}+u_{i}
$$

where $\mathrm{y}_{\mathrm{i}}$ is the ratio of private credit to GDP, $\mathrm{f}_{\mathrm{i}}$ is the share of bank assets held by foreign banks, $\mathbf{X}_{\mathbf{i}}$ is a matrix of control variables, $\mathrm{u}_{\mathrm{i}}$ is the error term, and $\alpha, \beta$, and $\boldsymbol{\gamma}$ are parameters to be estimated. The parameter of interest is $\beta$, the coefficient of the foreign bank share. We replicate this regression varying the set of control variables to examine the sensitivity of the coefficient of interest. To reduce joint endogeneity problems, whenever possible we measure right hand side variables at dates earlier than the dependent variable. Also, to reduce measurement error we average the control variables over 1991-98 whenever the data is available. Sources and definitions for the data are in Appendix 2.

\footnotetext{
${ }^{19}$ Contract enforcement is likely to be more important than the legal rights of creditors in low income countries, where laws are often not effectively enforced. In fact, Djankov, McLiesh, and Shleifer (2004) finds that measures of creditor rights do not significantly affect private credit in low income countries.
} 
An obvious problem with the cross-sectional regressions is that the market share of foreign banks is likely to be endogenous. A priori, it is not clear how endogeneity might bias the coefficient: foreign banks may be more prone to enter countries where, for exogenous reasons, financial development is particularly low, as in these markets growth prospects may be stronger. In this case, the OLS coefficient would be biased downwards. Conversely, business prospects for foreign banks may be poor in countries with little financial development to begin with, so foreign banks may be more prone to enter the more financially developed among low income countries, biasing the OLS coefficient upwards.

One strategy to address the endogeneity problem is to rely on fixed-effects panel estimation. With panel data, it is possible to control for unobserved country-specific fixed characteristics that might affect private credit, and rely on the within-country dimension to identify the parameter of interest. In other words, we will estimate whether within any given country a larger foreign bank presence is associated with less credit to the private sector. We are restricted by the availability of data to an average of 5 years of observation per country. As a result, we can use the panel at an annual frequency only, and cannot smooth out noise in the data by averaging over several years. We estimate the panel model first with OLS with country and time fixed effects and then with a system GMM estimator (Arellano and Bover, 2005), as is described in more detail in Section $\mathrm{V}$ below. The set of regressions we estimate can be summarized as follows:

$$
\ln y_{i, t}=\alpha+\mu \ln y_{i, t-1}+\beta f_{i, t}+\gamma \mathbf{X}_{\mathbf{i}, t}+\delta_{i}+u_{i, t}
$$

where the variables are defined as above, and $\delta_{i}$ is a country fixed effect. 
Another approach to address potential endogeneity as well as possible omitted country-specific effects is we test whether a larger foreign bank presence in year $\mathrm{t}$ is associated with less growth in credit in subsequent years. In this regression, the endogeneity bias should be upwards, as foreign banks presumably would not want to enter countries where financial performance is expected to worsen for exogenous reasons. In addition, in these regressions we control for performance in the initial year (as well as for other factors), so omitted country characteristics or shocks that affect private credit contemporaneously should not alter the coefficient of foreign bank share, because they should be already captured by the initial value of the performance indicator. This reduces concerns of joint endogeneity. Accordingly, the second set of regressions we estimate is as follows:

$$
\Delta \ln y_{i}=\alpha+\beta f_{i}+\delta y_{i 0}+\gamma \mathbf{X}_{\mathbf{i}}+u_{i}
$$

where $\mathrm{y}_{\mathrm{io}}$ is the performance indicator in an initial year, $\mathrm{f}_{\mathrm{i}}$ is the foreign bank share, $\mathrm{X}_{\mathrm{i}}$ is a vector of other controls, and $\mathrm{u}_{\mathrm{i}}$ is the error term.

A third strategy to deal with endogeneity is to rely on instrumental variable estimation. We will discuss instrumental variables regressions in Section V below.

\section{Bank Level Regressions}

The second empirical implication of the cream-skimming model is that foreign banks have a better quality loan portfolio than domestic banks within any given country. To test this prediction, we use a panel of bank level data for poor countries from Bankscope. The quality of a bank's loan portfolio is measured by the ratio of loan loss provisions to interest income. We obtain very similar results using the ratio of loan loss reserves to total assets. Data on 
non-performing loans is too sparse to be useful for our set of countries. Note that differences across countries in regulatory provisioning rules do not affect out tests, since we are comparing provisions across two groups of banks within a given country.

The empirical model for the bank level regressions is the following:

$$
\log \left(1+l l p_{i j t}\right)=\alpha+\beta f_{i j t}+\lambda \mathrm{X}_{i j t}+\theta_{j t}+\varepsilon_{i j} t
$$

where $l l p_{i j t}$ is the loan-loss provisioning of bank $i$ in country $j$ in year $t$, expressed as a share of net interest revenues, $f_{i j}$ is an indicator variable equal to one if bank $i$ in country $j$ in year $t$ is foreign-owned, $\mathrm{X}_{i j t}$ is a vector of bank level control variables, $\theta_{j t}$ is a matrix of country-time fixed effect, and $\varepsilon_{i j t}$ is the error term.

The inclusion of country-year fixed effects is a simple but general way to control for macroeconomic shocks simultaneously affecting the balance sheets of all banks in the same country in any given year. Thus, we estimate whether, in any given year, foreign-owned banks provision less for bad loans than domestic banks even after accounting for all potential common shocks. The set of bank-level control variables includes bank size, the loan-to-asset ratio, capitalization, profitability, overhead costs, and a dummy for government ownership. The regressions are estimated using OLS. Standard errors are clustered by country to allow for arbitrary correlation of error terms across banks within a given country.

\section{An Overview of the Data}

Private credit is positively and significantly correlated with GDP per capita, lack of corruption, and creditor information, and significantly negatively correlated with inflation, as 
expected (Table 2). Bivariate correlations with foreign bank penetration and with the contract enforcement variable are negative but not significant.

There are interesting cross-country differences in private credit and bank ownership (Figures 2-3). Foreign bank presence is especially pronounced in Sub-Saharan Africa, while it is most limited in the Middle East and North Africa and in Eastern Europe and Central Asia. ${ }^{20}$ Concerning financial depth, although differences within each region are substantial, on average banking systems in Asia and the Middle East and North Africa (MENA) are deeper. At the other extreme, financial development remains limited in most LICs in Eastern Europe and Central Asia and in Sub-Saharan Africa, while Latin America is somewhere in the middle.

Figure 4 shows a scatter plot of foreign bank penetration and private credit, indicating that countries with a larger foreign bank presence tend to have shallower credit markets. Figure 5 shows that countries where foreign penetration increased tended to experience less financial deepening.

Summary statistics for the bank level variables are in Table 3. The sample consists of 1,700-1,800 banks, depending on the specification. Loan loss provisions are not strongly correlated with other bank characteristics except for a negative correlation with profitability. In turn, profitability is negatively associated with size (perhaps because of the presence of large state banks) and the loan-to-asset ratio, but is positively correlated with costs.

\footnotetext{
${ }^{20}$ This would not be the case if we included upper-middle income countries in Eastern Europe, where foreign bank entry has been particularly strong.
} 


\section{Empirical Results}

\section{Country Level Tests-Cross-Sectional OLS regressions}

Table 4 presents various versions of the OLS regression of private credit on foreign share and other control variables. When we control for GDP per capita only, the coefficient of foreign share is negative but not significant. However, if we allow transition countries to have a different intercept, then the coefficient doubles in size, and becomes significant at the 5 percent confidence level. This suggests that omitting the transition dummy biases the foreign share coefficient upward. Adding inflation to the set of controls results in a further increase in the foreign share coefficient. As we introduce corruption and the business environment indicators, the fit of the regression improves and the coefficient of the foreign share and its standard error remain broadly unchanged. All the controls have the signs predicted by the theory and have significant coefficients. Additional controls, such as the share of bank assets in state owned banks, the concentration of the banking sector, and a variable proxying the size of government debt are not significant, do not change the foreign share coefficient much, and do not improve the fit of the model. These variables are therefore omitted from the benchmark specification. ${ }^{21}$

The magnitude of the effect of foreign bank presence on private credit is not trivial: an increase in the foreign share by one standard deviation leads to a decline in private credit of about 6 percentage points of GDP. This is about a third of the average ratio of private

\footnotetext{
${ }^{21}$ The same is true if we use indexes of political stability, internal conflict, military in power, rather than lack of corruption. Additional country characteristics, such as latitude, the density of the rural population, and the extent of controls on the powers of the executive are not significant and do not change the coefficient of the foreign share.
} 
credit to GDP in our sample. In Appendix 3 we show that this magnitude is consistent with a reasonable parameterization of the theoretical model.

Table 5 contains further robustness tests. The coefficient of the foreign share changes little when we use an alternative measure of foreign bank presence derived from a survey of supervisors rather than from Bankscope. Another concern is the endogeneity of GDP per capita, which might bias coefficients. If we omit GDP per capita or control for the level of development using GDP in 1980 - a more exogenous measure than the average GDP per capita over 1991-98, the relationship between foreign bank presence and financial depth does not change. Similar results obtain using GDP in 1970 (not reported).

In an additional robustness test, we replace the institutional control variables with measures of the "deep determinants" of institutions, namely legal origin and settlers' mortality (La Porta et al., 1998; Beck and Levine, 2003; Acemoglu, Johnson, and Robinson 2001). ${ }^{22}$ According to Acemoglu and Johnson (2005) legal origin is the deep determinant of contracting institutions, while settlers' mortality explains "property rights" institutions. Our specification amounts to estimating a reduced form equation in which institutional determinants of financial development are instrumented by their deep determinants. As it turns out, legal origin is not significantly correlated with private credit in our sample, while settlers' mortality is. ${ }^{23}$ More importantly, the coefficient of foreign ownership does not change much when we control for the deep determinants of institutions.

\footnotetext{
${ }^{22}$ In the sample including settlers' mortality there are no countries of German or Scandinavian legal origin nor any transition countries.

${ }^{23}$ We do not use settlers' mortality in the baseline regression to preserve sample size.
} 
A banking crisis may cause both a reduction in private credit and an increase in the foreign share, so omitting this variable may bias the results. As it turns out, however, the negative relationship between foreign share and private credit becomes stronger after controlling for crises. Controlling for the size of the informal sector does not change the results. ${ }^{24}$ The results are also robust to controlling for regional effects, the share of production in agriculture, or differences in export orientation across countries (results not reported). Finally, to ensure that the association between foreign bank presence and domestic banking sector depth does not reflect systematic differences of openness to capital inflows or outflows we control for capital account openness using the stock of foreign assets and liabilities. The coefficient on foreign bank presence remains significant.

We have also explored possible threshold effects by interacting foreign bank entry with various measures of institutional quality, to test whether the negative effects of foreign bank presence are more muted or reversed in countries with more advanced institutions. We do not find clear evidence of threshold effects of this sort, however, perhaps because threshold effects appear at a level of development beyond that of countries included in our sample. We take up this issue at the end of this Section.

To summarize, the OLS cross-sectional regressions indicate that there is a negative, significant, and robust correlation between the penetration of foreign banks in poor countries and the depth of the private credit market. In addition, the economic magnitude of the effect is quite substantial.

\footnotetext{
${ }^{24}$ Informal sector economy is defined as the market-based legal production of goods and services that are deliberately concealed from public authorities to avoid payment of taxes or to avoid regulations. Further details are available in Schneider (2005).
} 


\section{Panel Regressions}

A concern with cross-sectional regressions is that the relationship of interest may be disturbed by omitted country characteristics. The extensive robustness tests in the previous section help reducing this concern. As an alternative, we also estimate the relationship between foreign bank presence and private credit using panel data and controlling for country characteristics through country fixed effects. Table 6 reports these regression results. Given the persistence in the level of private credit, a lagged dependent variable is introduced in the regression as an additional control. Other control variables include inflation, which is significantly and negatively associated with private credit within a country, GDP per capita, which is positively albeit weakly associated with private credit, and the share of state banks, which is not significant. In these fixed effect regressions, the share of foreign banks is significantly and negatively associated with private credit to GDP in most specifications.

Fixed effects regressions of dynamic panels yield significantly biased OLS coefficients (Nickell, 1981), and that the size of the bias is larger the shorter the time dimension of the panel. Moreover, our RHS variables are also potentially endogenous, which would further bias the results. To address these issues, we estimate the model using the system GMM estimator developed by Arellano and Bover (1995). ${ }^{25}$ The system GMM estimator combines the use of lagged levels of the series as instruments for the pre-

\footnotetext{
${ }^{25}$ An alternative GMM estimator is the difference GMM estimator developed by Arellano and Bond (1991). However, it is well known that this estimator performs poorly for highly autoregressive panel series in finite samples (Blundell, Bond and Windmeijer, 2000), because lagged levels are poor instruments for the variables in differences.
} 
determined and endogenous variables in the equations in first differences, and the use of lagged differences of the dependent variable as instruments for equations in levels. A test of overidentifying restrictions (Sargan test) and tests of serial correlations for the error terms of the differenced equation support the validity of the instruments. Our key instrumentation strategy of foreign bank presence is that past foreign bank market share affects current credit to the private sector only through the current foreign bank market share.

Panel B of Table 6 presents various GMM regressions. The coefficient on the lagged dependent variable is close to one, which confirms that it is highly serially correlated, and justifies the use of the system GMM. Among the control variables considered, inflation is robustly and negatively associated with private credit, even after instrumentation. State banks also has a negative and significant coefficient, while GDP per capita is not significant. In all specifications, the presence of foreign banks is significantly and negatively associated with private credit, confirming the results of the cross-sectional regressions.

\section{Foreign Bank Presence and Credit Growth}

If a larger foreign presence is detrimental to private credit, then we should observe a negative correlation between foreign presence and subsequent credit growth. In this regression, controlling for the initial level of private credit should ensure that the results are not driven by the fact that foreign banks may choose to enter in more underbanked countries.

Table 7 presents these regression results. The dependent variable is computed as the $\log$ difference of the private credit-to-GDP ratio in 1999-2001 and in 1994-96. The basic specification includes as controls inflation and the share of state banks, both of which have a negative and significant effect on credit growth, and lack of corruption, which has a positive 
effect. GDP per capita and the transition dummy were not significant and have been omitted, though including these variables does not change the results. In this basic specification, a larger presence of foreign banks is associated with lower subsequent growth in credit to the private sector. The result holds also in a number of alternative specifications. Controlling for the occurrence of banking crises and a dummy for Sub-Saharan Africa does not change the results, and the same is true when we control for hyperinflation or changes in adult mortality rates, capturing the possible effects of the AIDS epidemics on growth.

Turning to the magnitude of the effect, based on the regression in column 3 , an increase in the foreign share of one standard deviation would lead to a decline in the growth rate of credit of about 20 percent, a sizable decline.

\section{Instrumental Variable Regressions}

An alternative approach to address endogeneity concerns is instrumental variable estimation. The challenge is to find instruments that explain foreign bank presence but have no other direct effects on private credit after controlling for other determinants of financial development. We use three sets of instruments to explain foreign bank penetration in poor countries: (i) the share of large international banks located in a former colonizing country of the host country; (ii) a measure of potential market size (population); and (iii) a measures of cultural distance based on language. ${ }^{26}$

\footnotetext{
${ }^{26}$ The data on international banks are from Cerutti, Dell'Ariccia, and Martinez Peria (2005), who construct them from Bankscope.
} 
The theory behind the first instrument is that large international banks are the primary source of supply of foreign direct investment in the banking sector and, moreover, a shared colonial past between the host country and the country of origin of an international bank means closer cultural and economic ties. Thus, we conjecture that a country whose former colonial power is well represented among global banks is, other things being equal, in a better position to attract foreign banks. In addition, it seems plausible that this instrument should not affect the overall size of private credit in the host country once foreign bank penetration and other institutional characteristics are controlled for, satisfying the exclusion assumption.

The second instrument is country size measured by population. In this case, the conjecture is that global banks operating in many markets can better diversify countryspecific risk than domestic banks, a benefit particularly valuable in smaller countries. In addition, in smaller countries a relatively small initial investment would give a foreign bank sufficient size to achieve a dominant position in the market. To be a valid instrument, population should not affect private credit through other channels. It may be argued that in larger countries it is easier for banks to achieve economies of scale, thereby reducing unit cost. Lower unit cost, in turn, would lead to lower interest rates and more lending. However, in separate regressions we find that population size is not a significant determinant of bank operating costs, suggesting that this channel is not operative in our sample. ${ }^{27}$

\footnotetext{
${ }^{27}$ Operating costs regressions are reported in an earlier version of this paper (IMF Working Paper WP/06/18).
} 
The third is a variable that measures how many European languages are official languages in the host country. ${ }^{28}$ This captures cultural proximity to Western Europe or North America, the areas of origin of the largest global banks. ${ }^{29}$

Our identification strategy relies upon the hypothesis that the instruments have no other direct nor indirect effects on domestic financial development. A potential concern is that measures of cultural and economic ties could proxy broad institutions in the host country, if for example countries with larger international banks happened to be more likely to set up deficient institutions in their colonies which then result in less private credit. However, the coefficient of the instrument in the first stage regression is not sensitive to the inclusion of broad institutional variables such as settlers' mortality, or specific institutions, such as the time to enforce contracts (Table 8). Another concern is that this variable could capture other omitted effects of international capital flows on the domestic financial system. However, our results are not affected by the introduction of various proxies for international financial integration. Moreover, if anything, capital flows (in particular equity and FDI liabilities) are positively, instead of negatively, associated with domestic financial development, which is inconsistent with such a concern. Finally, tests of overidentifying

\footnotetext{
${ }^{28}$ Data on languages are from the distance database of the CEPII, available at: http://www.cepii.fr/anglaisgraph/bdd/distances.htm.
}

${ }^{29}$ Of the top 100 banks in the world by asset size in 2002,83 were headquartered in a Western country (i.e., the United States and countries in Western Europe) or in Australia, while the remaining 17 were headquartered in Japan, China, South Korea, or India. The first group of banks were also more international than the second, operating in 16.9 different countries on average, as opposed to 8.4 countries on average for the Asian banks (Cerutti, et al., 2005). 
restrictions in regressions including another instrument do not reject the validity of the instrument.

In the first stage regressions, the instruments are highly significant, and the partial Rsquared is almost always above 20 percent (Table 8). Moreover, in specifications including our main instrument, the share of global banks from former colonizers, the F-test of joint significance of the instruments is very high. Stock and Yogo (2005) indicate that an F-test above 19 avoids weak instrument biases when using two instruments, under the strong criterion that the true significance level is 10 percent when the nominal level is 5 percent. All the F-tests of the regressions using our preferred instrument satisfy this condition. Thus, standard errors and $\mathrm{J}$ tests are unlikely to suffer from weak instrument biases. In specifications using only the other two instruments (population and European language), the F test is lower, but above or close to 10 , which is the threshold under the weaker condition that the bias of the IV regressions is less than 10 percent of the bias of the OLS regressions. As an additional check, we also report second stage confidence intervals for the foreign ownership variable that are robust to weak instrument bias (Moreira, 2003; Andrews, Moreira, and Stock, 2005).

In the second stage regressions, we do not reject the null hypothesis of validity of the overidentifying restrictions (Hansen J statistics) when more than one instrument is used. In addition, the coefficient of foreign share not only continues to be negative and significant, but becomes even slightly larger in size. This is the opposite of what should happen under the hypothesis that low financial development causes more foreign bank entry. In fact, these results suggest that instrumental variable estimation might be removing attenuation bias 
caused by measurement error. Altering the specification by changing the set of included controls does not change the coefficient estimate much.

As an alternative measure of cultural proximity we have also used religion: since global banks are primarily based in countries where the dominant religion is Protestant or Catholic, foreign bank presence should be smaller the larger the share of the population practices Islam, Buddhism, and Greek Orthodox Christianity. Religion turns out to be a somewhat weaker instrument than the others, but the significance of the foreign share in the second stage regression remains (results not reported).

While there are always questions about the suitability of instruments, we take these results as evidence that a larger presence of foreign banks reduces credit availability, consistent with the cream-skimming model.

\section{Loan Loss Provisions-Panel Regression Results}

As shown in the theoretical part of the paper, the cream-skimming model also implies that foreign banks should have a higher quality loan portfolio than domestic banks within any given country. We test this prediction using a panel of bank level data for a sample of poor countries. Loan quality is measured by the ratio of loan loss provisions to interest income. Regression results are in Table 9. Specifications differ depending on the control variables used. All regressions include country-time fixed effects to control for common macroeconomic shocks and country characteristics.

Not surprisingly, loan loss provisions are larger in banks that have a larger proportion of assets in the form of loans, that are less profitable, and have less capital. In addition, large banks have more loan loss provisions, although the significance of the coefficient is low. 
Higher operating cost are associated with higher loan quality, perhaps suggesting more intensive monitoring and screening of borrowers. More importantly, regardless of the specification, the dummy for foreign banks is always negative and significant, indicating that foreign banks have better quality loan portfolios than domestic banks. The dummy for state ownership, on the other hand, is not significant.

We find similar results when we measure loan quality using loan loss reserves as a share of assets, when we use time-averaged data in a cross-country specification, and when we include a lagged endogenous variable in the regression. Controlling for bank liquidity also does not alter the results.

To summarize, we find that foreign-owned banks provision less for bad loans than domestic banks in poor countries, even after controlling for observable bank characteristics and all potential sources of macroeconomic shocks affecting the balance sheets of all banks in a given country. This robust pattern is consistent with the "cream skimming" effect formalized in the theoretical model, whereby foreign-owned banks specialize and capture high-end customers.

It could be argued that foreign banks in poor countries have a better loan portfolio because they have a better risk management technology without necessarily engaging in cream-skimming. If better risk management by foreign banks is driving the result on loan loss provisions, we would expect foreign bank presence to increase overall credit in the country, which is the opposite of what we find in the data.

\section{Additional Empirical Results}




\section{Foreign Banks and Access to Banking Services}

We have interpreted the negative association between private sector credit and the presence of foreign banks in poor countries as the result of cream-skimming by these banks, in accordance with our theoretical model. To further bolster our interpretation, in this section we show that foreign bank presence in poor countries is associated with less access to financial services. While endogeneity issues are difficult to sort out given the small sample size, this is consistent with the hypothesis that it is the smaller, more opaque bank customers, possibly located in more remote regions, who suffer when foreign banks enter the market.

Indicators of access to financial services are from Beck et al. (2005). They include, among others, the extent of the branch and ATM networks, measuring the outreach of financial services, and the number of loans and deposit accounts, measuring actual usage of such services. Country coverage is uneven, especially for less developed countries, and for some indicators our sample becomes quite small. The information refers to the years 200304. Access indicators are not highly correlated with private credit in our sample, suggesting that a separate analysis is justified.

Table 10 shows regression results for access to financial services. The control variables are GDP per capita, population density, inflation, and corruption. Hence, financial access indicators tend to be worse in countries that had a large foreign bank presence in the mid-1990s, after controlling for the level of development or the institutional quality.

\section{Extending the Sample to Higher Income Countries}

An interesting question is whether the negative relationship between private credit and foreign bank penetration also hold when we extend the sample to include more advanced 
countries. Because most international banks are based in advanced countries, we expect differences in monitoring abilities between domestic and foreign banks to be less pronounced in advanced countries, so that cream-skimming is likely to be less widespread. Table 11 shows the baseline regressions for private credit for a sample including all 102 countries for which we have data. Regressions including only high income and upper-middle income countries are also presented. When we utilize the full sample, the coefficient of foreign banks becomes much smaller and is no longer significant, although it is still negative. This is because a larger foreign bank presence is associated with more rather than less private credit in high income countries (the coefficient is not significant, however).

\section{Conclusions}

A number of empirical studies find that, in poor countries, foreign banks tend to lend mainly to large firms (domestic or multinationals) and the government rather than smaller businesses for which local knowledge is necessary. In this paper, we have developed a theoretical model to study the effects of foreign bank entry when foreign banks have a cost advantage in lending to larger, more transparent firms but not in lending to smaller, more opaque customers. We find that while total lending, cost efficiency, and welfare may improve with foreign bank entry, this is not warranted. For some parameters configurations, a perverse effect may arise, whereby entry by foreign banks results in cream-skimming which increases overall operating costs, and lowers aggregate welfare. In addition, in all possible equilibria foreign bank entry only benefits more transparent firms, while other firms are either indifferent or worse off. 
The cream-skimming model predicts that countries with more foreign bank penetration should have a shallower banking sector, and that foreign banks should have a safer loan portfolio than domestic banks within each country. We find these predictions to be consistent with data from a sample of 60 lower income countries.

These findings are clearly at odds with hopes that foreign banks might replace inefficient and corrupt state and domestic banks and boost financial development in poor countries. On the other hand, they should not come as a surprise in light of recent research on banking, suggesting that lending to opaque businesses - which, arguably, constitute a large fraction of the economy in poor countries -- is not something large banks are particularly good at. Indeed, the recent trend towards greater consolidation in the banking business in advanced countries has raised concerns about the loss of "relationship capital" and the availability of credit to SMEs (Berger et al., 2005). Such concerns can only be heightened in the case of large international banks operating in poor countries, where cultural and geographic distance between loan officers and management is maximal. 


\section{References}

Acemoglu, Daron, Simon Johnson, and James A. Robinson, 2001, The Colonial Origins of Comparative Development, American Economic Review, Vol. 91, pp. 1369-1410.

Acemoglu, Daron and Simon Johnson, 2005, Unbundling Institutions, Journal of Political Economy, forthcoming.

Agénor, Pierre-Richard, 2001, Benefits and Costs of International Financial Integration: Theory and Facts, Policy and Research Working Paper No. 2699, The World Bank.

Andrews, Donald. W. K., Marcelo J. Moreira, and James H. Stock, 2006, Optimal Two-Sided Invariant Similar Tests for Instrumental Variables Regression, Econometrica, 74, 715-752.

Arellano, Manuel, and Olympia Bover 1995, Another Look at the Instrumental Variable Estimation of Error-Components Models, Journal of Econometrics, 68, 29-52.

Arellano, Manuel, and Stephen R. Bond, 1991, Some Tests of Specification for Panel Data: Monte Carlo Evidence and an Application to Employment Equations, Review of Economic Studies, 58, 277-297.

Arrow, Kenneth, 1973, Higher Education as a Filter, Journal of Public Economics, 2, 193-216.

Barth, James R., Gerard Caprio, and Ross Levine, 2001, "The Regulation and Supervision of Banks Around the World: A New Database," in Integrating Emerging Market Countries into the Global Financial System, ed. by R.E. Litan, and Richard Herring, Brookings-Wharton Papers on Financial Services, Brookings Institution Press, pp. 183-240.

Beck, Thorsten, Aslı Demirgüç-Kunt, and Ross Levine, 2003, Bank Competition, Financing Obstacles, and Access to Credit, World Bank Policy Research Working Paper No. 2996.

Beck, Thorsten, Aslı Demirgüç-Kunt, and Ross Levine, 2004, Finance, Inequality and Poverty: Crosscountry Evidence, NBER Working Paper 10979.

Beck, Thorsten, Aslı Demirgüç-Kunt, and Maria Soledad Martinez Peria, 2005, Reaching Out: Access to and Use of Banking Services Across Countries, unpublished manuscript, The World Bank.

Bekaert, Geert, Campbell R. Harvey, and Christian Lundblad, 2005, Does Financial Liberalization Spur Growth, Journal of Financial Economics, 77, 3-55.

Berger, Allen N., Rebecca Demsetz, and Philip E. Strahan, 1999, The Consolidation of the Financial Services Industry, Journal of Banking and Finance, 23. 
Berger, Allen N., Nathan H. Miller, Mitchell A. Petersen, Raghuram Rajan, and Jeremy Stein, 2005, Does Function Follow Organizational Form? Evidence from the Lending Practices of Large and Small Banks, Journal of Financial Economics, 76, pp. 237-269.

Black, Sandra E., and Philip E. Strahan, 2002, Entrepreneurship and the Availability of Bank Credit, Journal of Finance, 57, 2807-2833.

Blundell, Richard, Bond, Stephen R., and Frank Windmeijer (2000), Estimation in Dynamic Panel Data Models: Improving on the Performance of the Standard GMM Estimators, The Institute for Fiscal Studies, WP00/12.

Bonin, John, and Paul Wachtel, 2003, Financial Sector Development in Transition Economies: Lessons from the First Decade, Financial Markets, Institutions and Instruments, 12, 1, pp. 163.

Boyd, John H., Ross Levine, and Bruce D. Smith, 2001, The Impact of Inflation on Financial Sector Performance, Journal of Monetary Economics, Vol. 47, pp. 221-248.

Brownbridge, Martin, and Charles Harvey, 1998, Banking in Africa: The Impact of Financial Sector Reform Since Independence, (Trenton, NJ: Africa World Press).

Carow, K.A., Edward Kane, and R. Narayanan, 2004, How Have Borrowers Fared in Banking MegaMergers?, unpublished manuscript, Boston College.

Cerutti, Eugenio, Giovanni Dell'Ariccia, and Maria Soledad Martinez Peria, 2005, How Banks Go Abroad: Branches or Subsidiaries?, unpublished manuscript.

Claessens, Stijn, Aslı Demirgüç-Kunt, and Harry Huizinga, 2001, "How Does Foreign Entry Affect the Domestic Banking Market?” Journal of Banking and Finance, Vol. 25(5), pp. 891-911.

Clarke, George R.G., Robert Cull, and Maria Soledad Martinez-Peria, 2001, "Does Foreign Bank Penetration Reduce Access to Credit in Developing Countries? Evidence from Asking Borrowers," mimeo, World Bank (Washington: The World Bank).

Clarke, George, Cull, Robert, Maria Soledad Martinez Peria, and Susana M. Sanchez, 2005, Bank Lending to Small Businesses in Latin America: Does Bank Origin Matter?, Journal of Money, Credit, and Banking, Vol. 37, No. 1, pp. 83-118.

Degryse, Hans, Nancy Masschelein, and Janet Mitchell, 2005, SMEs and Bank Lending Relationships: The Impact of Mergers, CEPR Working Paper No. 5061.

Dell'Ariccia, Giovanni, and Robert Marquez, 2004, Information and Bank Credit Allocation, Journal of Financial Economics, 71, pp. 185-214. 
Demirgüç-Kunt, Asl1, and Enrica Detragiache, 2005, Cross-Country Empirical Studies of Systemic Distress: A Survey, National Institute Economic Review, 192, pp. 68-83.

Djankov, Simeon, Caralee McLiesh, and Andrei Shleifer, 2005, Private Credit in 129 Countries, NBER Working Paper No. 11078.

Giannetti, Maria Assunta, and Steven Ongena, 2005, Financial Integration and Entrepreneurial Activity: Evidence from Foreign Bank Entry in Emerging Markets, unpublished manuscript.

Goldberg, Linda S., B. Gerard Dages, and Daniel Kinney, 2000, "Foreign and Domestic Bank Participation in Emerging Markets: Lessons from Mexico and Argentina," Federal Reserve Bank of New York Economic Policy Review, September, pp.17-36.

Gormley, Todd A., 2005, Banking Competition in Developing Countries: Does Foreign Bank Entry Improve Credit Access?, unpublished manuscript, MIT, October 28th.

Gelos, Gaston, and Jorge Roldós, 2004, Consolidation and Market Structure in Emerging Market Banking Systems, Emerging Markets Review, 5, 39-59.

Goldsmith, Raymond W., 1969, Financial Structure and Development. New Haven, CT: Yale University Press.

Guiso, Luigi, Paola Sapienza, and Luigi Zingales, 2004, Does Local Financial Development Matter?, Quarterly Journal of Economics, 119, 929-969.

International Monetary Fund, 2000, International Capital Markets: Development, Prospects, and Key Policy Issues (Washington: International Monetary Fund).

Haber, Stephen, and Aldo Musacchio (2005), Foreign Banks and the Mexican Economy, 1997-2004, unpublished.

Karceski, Jason, Steven Ongena, and David C. Smith, 2005, The Impact of Bank Consolidation on Commercial Borrower Welfare, Journal of Finance, 60, pp. 2043-2082.

Kaufmann, Daniel, Kraay, Aart, and Massimo Mastruzzi, 2003, Governance Matters III: Governance Indicators for 1996-2002, World Bank.

Lane, Philip R., and Gian Maria Milesi-Ferretti, The External Wealth of Nations Mark II: Revised and Extended Estimates of Foreign Assets and Liabilities, 1970-2004", IMF Working Paper, 06/69.

La Porta, Rafael, Fernando Lopez de Silanes, Andrei Shleifer, and Robert W. Vishny, 1998, Law and Finance, Journal of Political Economy, 106, 6, pp. 1113-1155.

La Porta, Rafael, Fernando Lopez de Silanes, and Andrei Shleifer, 2002, Government Ownership of Commercial Banks, Journal of Finance, 57, 1, pp. 265-301. 
Levine, Ross, 1997, Financial Development and Economic Growth: Views and Agenda, Journal of Economic Literature, vol. 35(2), pp. 688-726.

Levine, Ross, 2005, Law, Endowments and Property Rights, Journal of Economic Perspectives, vol.19 (3), pp.61-88.

Levy-Yeyati, Eduardo, and Alejandro Micco, 2003, Concentration and Foreign Penetration in Latin American Banking Sectors: Impact on Competition and Risk, Research Department Working Paper No. 499, Inter-American Development Bank.

Lewis, Tracy and David Sappington, 1995, Insurance, Adverse Selection, and Cream-Skimming, Journal of Economic Theory, 65, 327-358.

Martinez Peria, Maria Soledad, and Ashoka Mody, forthcoming, How Foreign Participation and Market Concentration Impact Bank Spreads: Evidence from Latin America, Journal of Money, Credit, and Banking.

Micco, Alejandro, Ugo Panizza, and Mónica Yañez, 2004, Bank Ownership and Performance: Are Public Banks Different?, unpublished, Inter-American Development Bank.

Mian, Atif, 2006, Distance Constraints: The Limits of Foreign Lending in Poor Economies, Journal of Finance, Journal of Finance 61, 1465-1505.

Mian, Atif, 2003, Foreign, Private Domestic, and Government Banks: New Evidence from Emerging Markets, unpublished manuscript.

Moreira, Marcelo J., 2003, A Conditional Likelihood Test for Structural Models, Econometrica, 71:4, 1027-1048.

Nickell, Stephen J., 1981, Biases in Dynamic Models with Fixed Effects, Econometrica, 49, 14171426.

Peek, Joe, and Eric S. Rosengren, 2000, The Role of Foreign Banks in Latin America, mimeo, Federal Reserve Bank of Boston.

Petersen, Mitchell A., and Raghuram Rajan, 1995, The Effect of Credit Market Competition on Lending Relationships, Quarterly Journal of Economic, 110, pp. 407-443.

Sapienza, Paola, 2002, The Effects of Banking Mergers on Loan Contracts, Journal of Finance, 57, pp. 1891-1921.

Schneider, Friedrich, 2005, Shadow Economies of 145 Countries all over the World: Estimation Results over the Period 1999 to 2003, unpublished manuscript, University of Linz. 
Schulz, Heiner, 2006, Foreign Banks in Mexico: New Conquistadors or Agents of Change?, unpublished manuscript, University of Pennsylvania.

Staiger, Douglas, and James H. Stock, 1997, Instrumental Variables Regressions with Weak Instruments, Econometrica, 65, pp. 557-586.

Stein, Jeremy, 2002, Information Production and Capital Allocation: Decentralized Versus Hierarchical Firms, Journal of Finance, 57, pp. 1891-1921.

Stock, J. H., and M. Yogo, 2005, Testing for Weak Instruments in IV Regressions, in Identification and Inference for Econometric Models: A Festschrift in Honor of Thomas Rothenberg, Cambridge University Press. 


\section{Table 1. Theoretical Model: Equilibrium Values of Observable Variables}

The theoretical model predicts that one of four equilibria obtains depending on a several observable and unobservable parameters. To identify testable implications of the model, this table provides the equilibrium values of some observable variables. Countries with more foreign bank penetration have less bank credit and, within an individual country, foreign banks have smaller loan losses loans than domestic banks. Implications for overhead costs are ambiguous.

\begin{tabular}{|c|c|c|c|c|}
\hline & Pooling & Partially pooling & Separating & $\begin{array}{c}\text { Credit- } \\
\text { constrained }\end{array}$ \\
\hline Total output & $R\left(\mu_{H}+\mu_{S}+p \mu_{b}\right)$ & $R\left(\mu_{H}+\mu_{S}+p \mu_{b}\right)$ & $R\left(\mu_{H}+\mu_{S}\right)$ & $R \mu_{H}$ \\
\hline Total credit & 1 & 1 & $\mu_{H}+\mu_{S}$ & $\mu_{H}$ \\
\hline Credit/output & $\frac{1}{R\left(\mu_{h}+\mu_{s}+p \mu_{b}\right)}$ & $\frac{1}{R\left(\mu_{h}+\mu_{s}+p \mu_{b}\right)}$ & $\frac{1}{R}$ & $\frac{1}{R}$ \\
\hline $\begin{array}{l}\text { Foreign bank assets/ } \\
\text { bank assets }\end{array}$ & 0 & $\mu_{H}$ & $\frac{\mu_{H}}{\mu_{H}+\mu_{S}}$ & 1 \\
\hline $\begin{array}{l}\text { Loan losses/interest } \\
\text { earned in foreign } \\
\text { banks }\end{array}$ & No lending & 0 & 0 & 0 \\
\hline $\begin{array}{l}\text { Loan losses/interest } \\
\text { earned in domestic } \\
\text { banks }\end{array}$ & $(1-p) \mu_{b}$ & $\frac{(1-p) \mu_{B}}{\mu_{S}+\mu_{B}}$ & 0 & No lending \\
\hline $\begin{array}{l}\text { Overheads/Assets } \\
\text { foreign }\end{array}$ & 0 & $c_{H}-\Delta$ & $c_{H}-\Delta$ & $c_{H}-\Delta$ \\
\hline $\begin{array}{l}\text { Overheads/Assets } \\
\text { domestic }\end{array}$ & 0 & 0 & $c_{S}$ & No lending \\
\hline
\end{tabular}




\section{Table 2. Country-Level Variables - Summary Statistics}

This table provides summary statistics for country-level variables used in the benchmark cross-sectional regressions. The sample consists of 62 low-income and lower middle-income countries. Dependent variable is the ratio of bank credit to the private sector to GDP. Foreign ownership is the ratio of bank assets in banks controlled by foreigners to total bank assets in the country. GDP per capita is GDP in U.S. dollars divided by population. Inflation is the log difference in the consumer price index. Lack of corruption is an index measuring the freedom from corruption. Creditor information measures the cost to banks of obtaining information about borrowers. Enforcement speed is the inverse of the number of days it takes to enforce a basic business contract.

Private Credit

$\begin{array}{lc}\text { Number of observations } & 85 \\ \text { Mean } & 18.09 \\ \text { Standard deviation } & 15.71 \\ \text { Minimum } & 0.86 \\ \text { Maximum } & 93.26\end{array}$

Private credit

Private credit

1

Foreign ownership

Inflation

GDP per capita

Lack of corruption

Creditor information

Enforcement speed

significant at $10 \% ; *$ significant at $5 \%$
$-0.1241$

[0.3365]

$-0.1926^{*}$

[0.0831]

$0.468 * * *$

[0]

$0.4915 * * *$

[0]

$0.4559 * * *$

[0]

$-0.1644$

[0.145]
Foreign

ownership
Lack of

Inflation
GDP per capita corruption
Creditor information
1

$-0.2473 * *$
$[0.0547]$

[0.0547]

$-0.0782$

[0.5458]

$-0.0197$

[0.8785]

0.0241

[0.8538]

$-0.0018$

[0.9889]
1

0.1208

[0.2798]

$-0.1923 *$

[0.0816]

0.0584

[0.614]

0.1203

[0.2943]

\section{1}

$0.4089 * * *$

[0.0001]

$0.3593 * * *$

[0.0011]

$-0.055$

[0.6279]
1

0.1961 *

[0.0813]

$-0.3532 * * *$

[0.0012] 


\section{Table 3. Bank Level Variables - Summary statistics}

The table presents summary statistics for variables used in the bank level regressions. Loan loss provisions is the ratio of loan loss provisions to interest earned. Loans/Assets is the ratio of bank loans to total bank assets. Size is the log of bank assets divided by GDP. Foreign ownership is a dummy variable that takes the value of one if the bank is owned by a foreigner, while state ownership is a dummy for banks owned by the government. Capitalization is the ratio of equity to assets. Profitability is return on average assets. Costs is overhead costs to assets.

\begin{tabular}{lccccc}
\multicolumn{1}{c}{ Variable } & Number of obs. & Mean & $\begin{array}{c}\text { Std. } \\
\text { Dev. }\end{array}$ & Min & Max \\
\hline Loan Loss Provisions & 1714 & 27.12 & 37.78 & -0.85 & 526.09 \\
Loans/Assets & 1714 & 49.30 & 18.70 & 3.88 & 88.62 \\
Size & 1714 & -7.84 & 3.36 & -17.54 & -0.48 \\
Foreign ownership & 1714 & 0.29 & 0.45 & 0.00 & 1.00 \\
State ownership & 1714 & 0.08 & 0.26 & 0.00 & 1.00 \\
Capitalization & 1714 & 14.48 & 9.73 & 2.57 & 52.65 \\
Profitability & 1714 & 2.10 & 2.26 & -0.96 & 32.42 \\
Costs & 1712 & 0.06 & 0.07 & 0.00 & 1.71 \\
& & & & & \\
\hline
\end{tabular}

\section{Cross-correlations*}

\begin{tabular}{lccccc}
\hline & Loss Provisions & Loans/assets & Size & Capitalization & Profitability \\
\hline Loan Loss Provisions & 1 & & & & \\
Loans/assets & -0.09 & 1.00 & & & \\
& {$[0.4647]$} & & & & \\
Size & 0.07 & 0.22 & 1.00 & & \\
& {$[0.5641]$} & {$[0.0802]$} & & & \\
Capitalization & 0.04 & 0.06 & -0.16 & 1.00 & \\
& {$[0.7791]$} & {$[0.6196]$} & {$[0.2219]$} & & \\
Profitability & -0.27 & -0.36 & -0.24 & 0.22 & 1.00 \\
& {$[0.031]$} & {$[0.0038]$} & {$[0.056]$} & {$[0.0848]$} & 0.39 \\
Costs & -0.18 & -0.15 & -0.28 & 0.19 & $0.0017]$ \\
& {$[0.1644]$} & {$[0.2278]$} & {$[0.029]$} & {$[0.126]$} & {$[0.0017]$} \\
*p-values in brackets & & & & & \\
\hline
\end{tabular}




\section{Table 4}

\section{Private Credit and Foreign Bank Presence in Poor Countries: OLS Cross-Sectional Regressions}

This table reports the results of cross-sectional OLS regressions for the sample of poor countries. The dependent variable is the ratio of bank credit to the private sector to GDP. GDP per capita is GDP in U.S. dollars divided by population. Foreign ownership is the ratio of bank assets in banks controlled by foreigners to total bank assets in the country. Transition is a dummy variable for formerly centrally planned economies. Inflation is the log difference in the consumer price index. Lack of corruption is an index measuring the freedom from corruption. Creditor information measures the cost to banks of obtaining information about borrowers. Enforcement speed is the inverse of the number of days it takes to enforce a basic business contract. State banks is the share of bank assets in state-owned banks. Concentration is the share of bank assets in the five largest banks. Fiscal is the ratio of interest payments on public debt to the stock of public debt.

\begin{tabular}{|c|c|c|c|c|c|c|c|c|}
\hline & (1) & (2) & (3) & (4) & (5) & (6) & (7) & $(8)$ \\
\hline \multirow[t]{2}{*}{ GDP per capita } & 7.04 & 8.16 & 9.05 & 6.99 & 5.65 & 5.17 & 6.38 & 6.56 \\
\hline & {$[3.50]^{* * *}$} & {$[3.94]^{* * *}$} & {$[5.59]^{* * *}$} & {$[4.57]^{* * *}$} & {$[3.40]^{* * *}$} & {$[3.07]^{* * *}$} & {$[2.84]^{* * *}$} & {$[2.69]^{* *}$} \\
\hline \multirow[t]{2}{*}{ Foreign ownership } & -6.59 & -15.3 & -22.56 & -19.6 & -18.88 & -21.5 & -23.4 & -23.78 \\
\hline & {$[0.94]$} & {$[2.20] * *$} & {$[3.31]^{* * *}$} & {$[3.37]^{* * *}$} & {$[3.09]^{* * *}$} & {$[3.35]^{* * *}$} & {$[3.42]^{* * *}$} & {$[3.48]^{* * *}$} \\
\hline \multirow[t]{2}{*}{ Transition } & & -14.33 & -8.88 & -6.99 & -5.2 & -4.82 & -10.02 & -8.92 \\
\hline & & {$[3.05]^{* * *}$} & {$[2.31]^{* *}$} & {$[1.95]^{*}$} & {$[1.34]$} & {$[1.17]$} & {$[2.16]^{* *}$} & {$[1.83]^{*}$} \\
\hline \multirow[t]{2}{*}{ Inflation } & & & -7.02 & -5.92 & -5.76 & -5.53 & -4.3 & -4.41 \\
\hline & & & {$[4.67]^{* * *}$} & {$[4.30]^{* * *}$} & {$[4.13]^{* * *}$} & {$[3.79]^{* * *}$} & {$[2.80]^{* * *}$} & {$[2.74]^{* * *}$} \\
\hline \multirow[t]{2}{*}{ Lack of corruption } & & & & 10.54 & 8.45 & 9.42 & 9.84 & 8.92 \\
\hline & & & & {$[2.67]^{* *}$} & {$[2.00]^{*}$} & {$[2.21]^{* *}$} & {$[1.58]$} & [1.42] \\
\hline \multirow[t]{2}{*}{ Creditor information } & & & & & 1.48 & 1.46 & 0.8 & 0.84 \\
\hline & & & & & {$[2.34] * *$} & {$[2.24] * *$} & {$[1.01]$} & {$[1.03]$} \\
\hline \multirow[t]{2}{*}{ Enforcement speed } & & & & & 423.6 & 411.41 & 367.52 & 392.44 \\
\hline & & & & & {$[2.78]^{* * *}$} & {$[2.70]^{* * *}$} & {$[1.94]^{*}$} & {$[2.11]^{* *}$} \\
\hline \multirow[t]{2}{*}{ State banks } & & & & & & -5.42 & -11.64 & -12.76 \\
\hline & & & & & & [0.99] & [1.39] & {$[1.57]$} \\
\hline \multirow[t]{2}{*}{ Concentration } & & & & & & & -7.27 & -5 \\
\hline & & & & & & & [0.99] & {$[0.57]$} \\
\hline \multirow[t]{2}{*}{ Fiscal } & & & & & & & & 0.73 \\
\hline & & & & & & & & {$[1.23]$} \\
\hline Observations & 62 & 62 & 61 & 61 & 59 & 59 & 45 & 45 \\
\hline R-squared & 0.21 & 0.34 & 0.56 & 0.61 & 0.63 & 0.64 & 0.66 & 0.67 \\
\hline
\end{tabular}




\section{Table 5}

\section{Private Credit and Foreign Banks in Poor Countries: Robustness Tests}

This table reports the results of cross-sectional OLS regressions for the sample of poor countries. The dependent variable is the ratio of bank credit to the private sector to GDP. GDP per capita is GDP in U.S. dollars divided by population. Foreign ownership is the ratio of bank assets in banks controlled by foreigners to total bank assets in the country. Transition is a dummy variable for formerly centrally planned economies. Inflation is the log difference in the consumer price index. Lack of corruption is an index measuring the freedom from corruption. Creditor information measures the cost to banks of obtaining information about borrowers. Enforcement speed is the inverse of the number of days it takes to enforce a basic business contract. Settler's mortality is the mortality rate of settlers who colonized the country (Acemoglu, Johnson, and Robinson, 2001). French legal origin is a dummy variable for countries where the legal system is derived from the French Civil Code. Banking crises are dummies for the occurrence of a systemic banking crisis in the period indicated (constructed from Detragiache and DemirgüçKunt). Informal sector is the share of the informal sector in the economy from Schneider (2005). Foreign assets (liabilities) measure stock of foreign (domestic) claims in the hands of domestic (foreign) residents as a share of GDP.

\begin{tabular}{|c|c|c|c|c|c|c|c|c|}
\hline & Benchmark & (1) & (2) & (3) & (4) & (5) & (8) & (13) \\
\hline \multirow[t]{2}{*}{ GDP per capita } & 5.65 & 6.35 & & & 8.21 & 5.18 & 5.55 & 6.27 \\
\hline & {$[3.40]^{* * *}$} & {$[2.54]^{* *}$} & & & {$[4.18]^{* * *}$} & {$[2.84]^{* * *}$} & {$[3.22]^{* * *}$} & {$[2.95]^{* * *}$} \\
\hline \multirow[t]{2}{*}{ Foreign ownership } & -18.88 & & -16.17 & -18.26 & -19.62 & -21.66 & -20.46 & -20.01 \\
\hline & {$[3.09]^{* * *}$} & & {$[2.49]^{* *}$} & {$[2.73]^{* * *}$} & {$[2.40]^{* *}$} & {$[3.27]^{* * *}$} & {$[-3.37] * * *$} & {$[2.78] * * *$} \\
\hline \multirow[t]{2}{*}{ Foreign banks (Barth et al.) } & & -13.49 & & & & & & \\
\hline & & {$[2.76]^{* * *}$} & & & & & & \\
\hline \multirow[t]{2}{*}{ Transition } & -5.2 & -4.06 & -0.82 & -12.35 & & -4.98 & -4.53 & -4.79 \\
\hline & [1.34] & [1.11] & {$[0.28]$} & {$[3.55]^{* * *}$} & & {$[1.56]$} & {$[-1.12]$} & {$[1.15]$} \\
\hline \multirow{2}{*}{ Inflation } & -5.76 & -5.02 & -4.58 & -5.81 & -7.3 & -6.07 & -6.21 & -5.4 \\
\hline & {$[4.13]^{* * *}$} & {$[3.57]^{* * *}$} & {$[4.04]^{* * *}$} & {$[3.28]^{* * *}$} & {$[3.84]^{* * *}$} & {$[4.71] * * *$} & {$[-3.99]^{* * *}$} & {$[3.38]^{* * *}$} \\
\hline \multirow[t]{2}{*}{ Lack of corruption } & 8.45 & 4.4 & 13.64 & 10.58 & & 9.09 & 8.80 & 7.58 \\
\hline & {$[2.00]^{*}$} & {$[0.76]$} & {$[2.92]^{* * *}$} & {$[2.34]^{* *}$} & & {$[2.13]^{* *}$} & {$[2.15]^{* *}$} & {$[1.63]$} \\
\hline \multirow[t]{2}{*}{ Enforcement speed } & 1.48 & 580.33 & 547.14 & 396.5 & & 396.56 & 425.67 & 424.09 \\
\hline & {$[2.34]^{* *}$} & {$[3.32]^{* * *}$} & {$[3.79]^{* * *}$} & {$[2.26]^{* *}$} & & {$[2.38]^{* *}$} & {$[2.62]^{* * *}$} & {$[2.03]^{* *}$} \\
\hline \multirow[t]{2}{*}{ Creditor information } & 423.6 & 2.54 & 2.63 & 1.55 & & 1.41 & 1.71 & 1.64 \\
\hline & {$[2.78]^{* * *}$} & {$[2.58]^{* *}$} & {$[3.92]^{* * *}$} & {$[2.10]^{* *}$} & & {$[2.28]^{* *}$} & {$[2.52]^{* * *}$} & {$[2.34]^{* *}$} \\
\hline \multirow[t]{2}{*}{ GDP per capita 1980} & & & & 5.4 & & & & \\
\hline & & & & {$[2.51]^{* *}$} & & & & \\
\hline \multirow[t]{2}{*}{ Settlers' mortality } & & & & & -4.59 & & & \\
\hline & & & & & {$[2.24] * *$} & & & \\
\hline French legal origin & & & & & $\begin{array}{l}-0.46 \\
\lceil 0.14]\end{array}$ & & & \\
\hline \multirow[t]{2}{*}{ Banking crisis $1990-93$} & & & & & & -4.82 & & \\
\hline & & & & & & [1.66] & & \\
\hline \multirow[t]{2}{*}{ Banking crisis 1994-2002 } & & & & & & 3.38 & & \\
\hline & & & & & & [0.97] & & \\
\hline \multirow[t]{2}{*}{ Informal Sector } & & & & & & & 0.09 & \\
\hline & & & & & & & {$[0.48]$} & \\
\hline \multirow[t]{2}{*}{ Foreign liabilities } & & & & & & & & 2.43 \\
\hline & & & & & & & & {$[0.68]$} \\
\hline \multirow[t]{2}{*}{ Foreign assets } & & & & & & & & -2.8 \\
\hline & & & & & & & & {$[0.32]$} \\
\hline Observations & 59 & 54 & 59 & 48 & 41 & 59 & 58 & 54 \\
\hline R-squared & 0.63 & 0.65 & 0.56 & 0.61 & 0.63 & 0.66 & 0.64 & 0.62 \\
\hline Robust t-statistics in bracket & significa & $10 \% ; *$ & gnifican & $\% ; * * * \mathrm{~s}$ & ficant a & & & \\
\hline
\end{tabular}




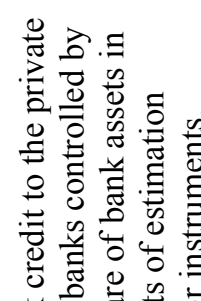

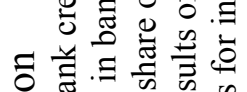

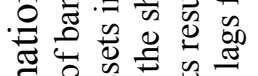

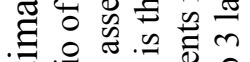

, s.

世

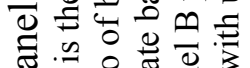

as

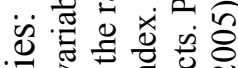

들

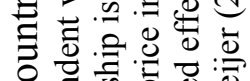

S

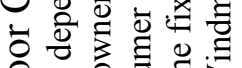

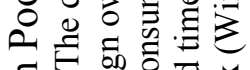

o. $\exists$ क्.

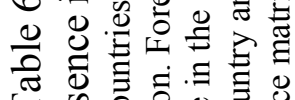

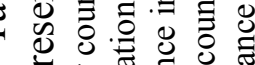

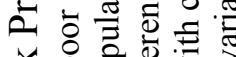

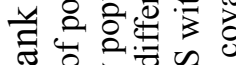

ص 응

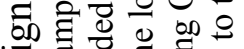

.

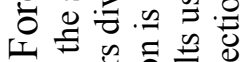

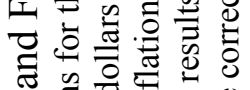

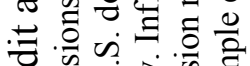

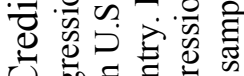

Ч

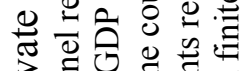

.

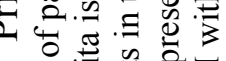

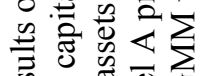

Ð

¿ है है

Еิ

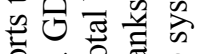

ํํㅇ 웡 है

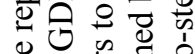

웜월

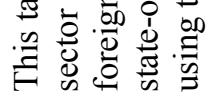

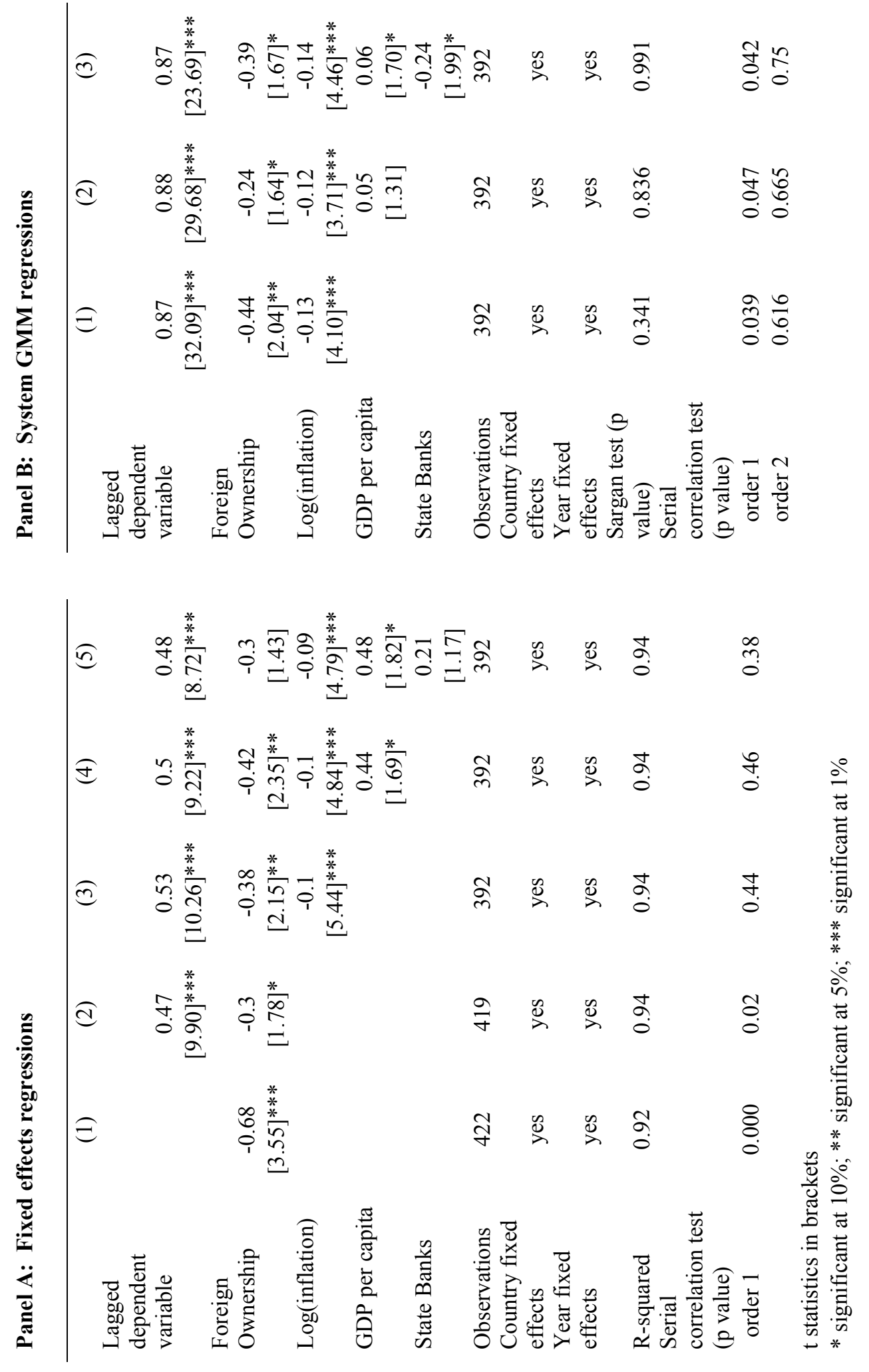


Table 7

Foreign Bank Presence and Private Credit Growth in Poor Countries

This table reports the results of cross-sectional OLS regressions for the sample of poor countries. The dependent variable is the log difference in the ratio of bank credit to the private sector to GDP between 1995-98 and 19992002. Initial depth is the ratio of bank credit to the private sector measured in 1995-98. Foreign ownership is the ratio of bank assets in banks controlled by foreigners to total bank assets in the country. Inflation is the log difference in the consumer price index. Lack of corruption is an index measuring the freedom from corruption. Banking crises are dummies for the occurrence of a systemic banking crisis in the period indicated (constructed from Detragiache and Demirgüç-Kunt). Africa is a dummy for countries in Sub-Saharan Africa. Change in mortality is the change in the mortality rate of the population between 2002 and 1995. Hyperinflation is a dummy variable for countries that experienced a hyperinflation during 1995-2002.

\begin{tabular}{|c|c|c|c|c|c|c|}
\hline & (1) & (2) & (3) & (4) & (5) & (6) \\
\hline \multirow[t]{2}{*}{ Initial depth } & -0.01 & -0.02 & -0.02 & -0.02 & -0.02 & -0.02 \\
\hline & {$[3.38]^{* * *}$} & {$[4.57]^{* * *}$} & {$[4.83]^{* * *}$} & {$[5.12]^{* * *}$} & {$[3.84]^{* * *}$} & {$[4.49]^{* *}$} \\
\hline \multirow[t]{2}{*}{ Foreign ownership } & -0.55 & -0.56 & -0.68 & -0.52 & -0.58 & -0.54 \\
\hline & {$[2.29] * *$} & {$[2.42] * *$} & {$[2.77] * * *$} & {$[2.05] * *$} & {$[2.12] * *$} & {$[2.33] * *$} \\
\hline \multirow[t]{2}{*}{ Inflation } & -0.09 & -0.08 & -0.1 & -0.11 & -0.08 & -0.12 \\
\hline & {$[2.13]^{* *}$} & {$[1.98]^{*}$} & {$[2.68]^{* * *}$} & {$[2.87]^{* * *}$} & {$[1.84]^{*}$} & {$[2.42]^{* *}$} \\
\hline \multirow[t]{2}{*}{ State banks } & -0.35 & -0.4 & -0.38 & -0.37 & -0.37 & -0.43 \\
\hline & {$[1.73]^{*}$} & {$[2.05]^{* *}$} & {$[1.85]^{*}$} & {$[1.80]^{*}$} & [1.62] & {$[2.26]^{* *}$} \\
\hline \multirow[t]{2}{*}{ Lack of corruption } & & 0.3 & 0.33 & 0.34 & 0.32 & 0.29 \\
\hline & & {$[2.44]^{* *}$} & {$[2.69]^{* * *}$} & {$[2.87]^{* * *}$} & {$[2.01]^{*}$} & {$[2.37]^{* *}$} \\
\hline \multirow[t]{2}{*}{ Banking crisis $1990-93$} & & & -0.16 & -0.15 & & \\
\hline & & & {$[1.16]$} & {$[1.07]$} & & \\
\hline \multirow[t]{2}{*}{ Banking crisis $1994-2002$} & & & 0.16 & 0.13 & & \\
\hline & & & {$[2.01]^{* *}$} & {$[1.52]$} & & \\
\hline \multirow[t]{2}{*}{ Africa } & & & & -0.2 & & \\
\hline & & & & {$[1.76]^{*}$} & & \\
\hline \multirow[t]{2}{*}{ Change in mortality } & & & & & -0.01 & \\
\hline & & & & & {$[0.06]$} & \\
\hline Hyperinflation & & & & & & $\begin{array}{c}0.2 \\
{[0.88]}\end{array}$ \\
\hline Observations & 59 & 59 & 59 & 59 & 50 & 59 \\
\hline R-squared & 0.23 & 0.29 & 0.34 & 0.38 & 0.29 & 0.3 \\
\hline
\end{tabular}


Table 8

Private Credit and Foreign Bank Presence in Poor Countries: Instrumental Variables Estimation

The table reports results of 2SLS estimation of the relationship between private credit and foreign bank presence. The dependent variable is bank credit to the private sector (in percent of GDP). GDP per capita is GDP in U.S. dollars divided by population. Foreign ownership is the ratio of bank assets in banks controlled by foreigners to total bank assets. Transition is a dummy variable for formerly centrally planned economies. Inflation is the log difference in the consumer price index. Lack of corruption is an index measuring freedom from corruption. Creditor information measures the cost to banks of obtaining information about borrowers. Enforcement speed is the inverse of the number of days it takes to enforce a basic business contract. The instruments are the share of top 100 international banks located in former colonizer countries (banks from colonizer), log of population, and a dummy for using a European language as official language.

\begin{tabular}{|c|c|c|c|c|c|c|c|c|c|}
\hline Second Stage & (1) & (2) & (3) & (4) & (2) & (3) & (4) & (5) & (6) \\
\hline \multirow[t]{2}{*}{ Foreign Ownership } & -23.29 & -24.43 & -31.13 & -25.01 & -27.6 & -32.67 & -25.2 & -31.2 & -31.57 \\
\hline & {$[1.75]^{*}$} & {$[2.16] * *$} & {$[2.50]^{* *}$} & {$[2.26]^{* *}$} & {$[2.74] * * *$} & {$[2.46] * *$} & {$[2.31] * *$} & {$[2.10]^{* *}$} & {$[2.18]^{* *}$} \\
\hline \multirow[t]{2}{*}{ Transition } & -5.9 & -7.57 & -9.74 & -8.53 & & -4.73 & -6.16 & -7.07 & -7.14 \\
\hline & [1.40] & {$[2.08]^{* *}$} & {$[2.60]^{* * *}$} & {$[2.24]^{* *}$} & & {$[1.22]$} & [1.63] & {$[1.77]^{*}$} & {$[1.76]^{*}$} \\
\hline \multirow[t]{2}{*}{ GDP per capita } & 5.99 & 7.19 & 9.23 & 7.45 & 8.2 & 4.87 & 5.86 & 6.06 & 6.18 \\
\hline & {$[3.77]^{* * *}$} & {$[4.54]^{* * *}$} & {$[5.77]^{* * *}$} & {$[4.63]^{* * *}$} & {$[3.49]^{* * *}$} & {$[2.84]^{* * *}$} & {$[3.71]^{* * *}$} & {$[3.70]^{* * *}$} & {$[3.77]^{* * *}$} \\
\hline \multirow[t]{2}{*}{ Inflation } & -5.98 & -6.19 & -7.37 & -6.37 & -7.84 & -6.48 & -6.09 & -6.41 & -6.42 \\
\hline & {$[4.20]^{* * *}$} & {$[4.19]^{* * *}$} & {$[4.76]^{* * *}$} & {$[4.29]^{* * *}$} & {$[4.17]^{* * *}$} & {$[5.03]^{* * *}$} & {$[4.47]^{* * *}$} & {$[4.44]^{* * *}$} & {$[4.49]^{* * *}$} \\
\hline \multirow[t]{2}{*}{ Lack of corruption } & 7.64 & 9.9 & & 9.6 & & 6.55 & 7.83 & 7.24 & 6.99 \\
\hline & {$[1.81]^{*}$} & {$[2.44]^{* *}$} & & {$[2.49]^{* *}$} & & {$[1.71]^{*}$} & {$[1.99]^{* *}$} & {$[1.82]^{*}$} & {$[1.71]^{*}$} \\
\hline \multirow{2}{*}{ Enforcement speed } & 418.38 & & & & & 42.64 & 402.73 & 382.93 & 386.86 \\
\hline & {$[2.79]^{* * *}$} & & & & & {$[0.21]$} & {$[2.86]^{* * *}$} & {$[2.69]^{* * *}$} & {$[2.62]^{* * *}$} \\
\hline \multirow[t]{2}{*}{ Creditor information } & 1.47 & & & & & 1.48 & 1.41 & 1.35 & 1.37 \\
\hline & {$[2.32]^{* *}$} & & & & & {$[2.09]^{* *}$} & {$[2.33]^{* *}$} & {$[2.08]^{* *}$} & {$[2.05]^{* *}$} \\
\hline \multirow[t]{2}{*}{ FDI Liabilities } & & & & & & 24.54 & & & \\
\hline & & & & & & {$[2.49]^{* *}$} & & & \\
\hline \multirow[t]{2}{*}{ Portfolio Equity Liabilities } & & & & & & 180.73 & & & \\
\hline & & & & & & {$[1.77]^{*}$} & & & \\
\hline \multirow[t]{2}{*}{ Settler mortality } & & & & & -4.17 & & & & \\
\hline & & & & & {$[1.73]^{*}$} & & & & \\
\hline \multirow[t]{2}{*}{ French legal origin } & & & & -1.55 & 0.23 & & & & \\
\hline & & & & {$[0.56]$} & {$[0.07]$} & & & & \\
\hline Observations & 58 & 60 & 60 & 60 & 40 & 56 & 59 & 59 & 58 \\
\hline R-squared & 0.63 & 0.61 & 0.55 & 0.61 & 0.62 & 0.66 & 0.62 & 0.61 & 0.6 \\
\hline Hansen J stat & 0.82 & 0.08 & 0.02 & 0.01 & 0.01 & 0.46 & 1.03 & . & 0.01 \\
\hline $\begin{array}{l}\text { P-val } \\
90 \text { percent confidence } \\
\text { interval (CLR) }\end{array}$ & $\begin{array}{r}0.36 \\
{[-25.8} \\
-21.4] \\
\end{array}$ & $\begin{array}{l}0.78 \\
{[-26.5} \\
-22.4] \\
\end{array}$ & $\begin{array}{l}0.88 \\
{[-33.2} \\
-29.1]\end{array}$ & $\begin{array}{l}0.93 \\
{[-33.8} \\
-29.7] \\
\end{array}$ & $\begin{array}{r}0.93 \\
{[-20.0} \\
-15.3] \\
\end{array}$ & $\begin{array}{r}0.50 \\
{[-24.6} \\
-19.9] \\
\end{array}$ & $\begin{array}{l}0.31 \\
{[-27.4} \\
-23.6] \\
\end{array}$ & $\begin{array}{l}{[-33.3,} \\
-29.1] \\
\end{array}$ & $\begin{array}{l}0.91 \\
{[-33.6} \\
-29.6]\end{array}$ \\
\hline \multicolumn{10}{|l|}{ First Stage } \\
\hline \multirow[t]{2}{*}{ Banks from colonizer } & 2.59 & 2.69 & 2.76 & 2.69 & 3.06 & 2.62 & 2.21 & & \\
\hline & {$[6.96]^{* * *}$} & {$[8.25]^{* * *}$} & {$[12.27]^{* * *}$} & {$[6.49]^{* * *}$} & {$[8.47]^{* * *}$} & {$[5.57]^{* * *}$} & {$[4.94]^{* * *}$} & & \\
\hline \multirow[t]{2}{*}{ Population } & & & & & & & -0.05 & -0.06 & -0.05 \\
\hline & & & & & & & {$[-4.02]^{* * *}$} & {$[-4.22]^{* * *}$} & {$[-3.36]^{* * *}$} \\
\hline \multirow[t]{2}{*}{ European language } & 0.16 & 0.16 & 0.16 & 0.16 & 0.15 & 0.17 & & & 0.12 \\
\hline & {$[2.8]^{* * *}$} & {$[3.12]^{* * *}$} & {$[3.09]^{* * *}$} & {$[3.1]^{* * *}$} & {$[2.92]^{* * *}$} & {$[2.81]^{* * *}$} & & & {$[2.16]^{* *}$} \\
\hline \multirow{2}{*}{$\begin{array}{l}\text { Partial R-squared } \\
\text { F statistic (excluded } \\
\text { instruments) }\end{array}$} & 0.19 & 0.21 & 0.22 & 0.20 & 0.28 & 0.21 & 0.24 & 0.18 & 0.23 \\
\hline & 37.68 & 46.21 & 107.08 & 30.59 & 48.07 & 24.19 & 41.34 & 17.81 & 10.63 \\
\hline$p$-value of $F$ test & 0.0000 & 0.0000 & 0.0000 & 0.0000 & 0.0000 & 0.0000 & 0.0000 & 0.0001 & 0.0001 \\
\hline
\end{tabular}

Robust $\mathrm{z}$ statistics in brackets. * significant at $10 \%$; * significant at $5 \%$; *** significant at $1 \%$ 


\section{Table 9. Panel Regressions-Loan Loss Provisions}

The table presents OLS regression results for a panel of banks from poor countries. Dependent variable is the ratio of loan loss provisions to interest earned. Loans/Assets is the ratio of bank loans to total bank assets. Size is the log of bank assets divided by GDP. Foreign ownership is a dummy variable for foreignowned banks, while state-owned is a dummy for banks owned by the government. Capitalization is the ratio of equity to assets. Profitability is return on average assets. Costs is overhead costs to assets. Regressions include country-year fixed effects to control for common country characteristics and macroeconomic shocks. Standard errors are clustered by country.

\begin{tabular}{|c|c|c|c|c|c|c|}
\hline & (1) & (2) & (3) & (4) & (5) & (6) \\
\hline Foreign & $\begin{array}{c}-0.24 \\
{[3.03]^{* * *}}\end{array}$ & $\begin{array}{c}-0.27 \\
{[3.32]^{* * *}}\end{array}$ & $\begin{array}{c}-0.28 \\
{[3.38]^{* * * *}}\end{array}$ & $\begin{array}{c}-0.26 \\
{[3.17] * * *}\end{array}$ & $\begin{array}{c}-0.27 \\
{[3.43]^{* * *}}\end{array}$ & $\begin{array}{c}-0.27 \\
{[3.49]^{* * *}}\end{array}$ \\
\hline Loans /assets & $\begin{array}{c}0.54 \\
{[6.42]^{* * *}}\end{array}$ & $\begin{array}{c}0.54 \\
{[6.48]^{* * *}}\end{array}$ & $\begin{array}{c}0.54 \\
{[6.38]^{* * *}}\end{array}$ & $\begin{array}{c}0.51 \\
{[6.17]^{* * *}}\end{array}$ & $\begin{array}{c}0.50 \\
{[6.09]^{* * *}}\end{array}$ & $\begin{array}{c}0.51 \\
{[6.20]^{* * *}}\end{array}$ \\
\hline Size & & $\begin{array}{c}0.07 \\
{[2.75]^{* * *}}\end{array}$ & $\begin{array}{c}0.07 \\
{[2.78]^{* * *}}\end{array}$ & $\begin{array}{c}0.00 \\
{[0.06]}\end{array}$ & $\begin{array}{c}0.07 \\
{[2.06]^{* *}}\end{array}$ & $\begin{array}{c}0.06 \\
{[1.77]^{*}}\end{array}$ \\
\hline State-owned & & & $\begin{array}{l}-0.10 \\
{[0.72]}\end{array}$ & $\begin{array}{l}-0.07 \\
{[0.49]}\end{array}$ & $\begin{array}{c}-0.22 \\
{[1.70]^{*}}\end{array}$ & $\begin{array}{l}-0.21 \\
{[1.63]}\end{array}$ \\
\hline Capitalization & & & & $\begin{array}{c}-0.33 \\
{[4.15]^{* * *}}\end{array}$ & $\begin{array}{c}-0.19 \\
{[2.14]^{* *}}\end{array}$ & $\begin{array}{c}-0.19 \\
{[2.07]^{* *}}\end{array}$ \\
\hline Profitability & & & & & $\begin{array}{c}-0.25 \\
{[3.76]^{* * *}}\end{array}$ & $\begin{array}{c}-0.25 \\
{[3.70]^{* * *}}\end{array}$ \\
\hline Costs & & & & & & $\begin{array}{c}-1.40 \\
{[2.24]^{* *}}\end{array}$ \\
\hline Observations & 1876 & 1864 & 1864 & 1864 & 1714 & 1712 \\
\hline R-squared & 0.3 & 0.31 & 0.31 & 0.32 & 0.37 & 0.37 \\
\hline Number of banks & 872 & 866 & 866 & 866 & 812 & 811 \\
\hline Country-year fixed effects & yes & yes & yes & yes & yes & yes \\
\hline Bank clusters & yes & yes & yes & yes & yes & yes \\
\hline
\end{tabular}


Table 10

Access to Financial Services and Foreign Bank Presence in Poor Countries: Cross-Sectional OLS Regressions

This table reports OLS cross-sectional regression results on the relationship between foreign bank presence and access to finance. The dependent variables are five alternative indicators of access to financial services from Beck et al. (2005). Demographic branch penetration is the number of bank branches divided by population. Geographic branch (ATM) penetration is the number of bank branches (ATM machines) divided by the area of the country (in square miles). Loan accounts per capita is the number of bank accounts in the country divided by population. foreign bank penetration, and credit to the private sector. GDP per capita is GDP in U.S. dollars divided by population. Population density is population per square mile. Foreign ownership is the ratio of bank assets in banks controlled by foreigners to total bank assets in the country. Inflation is the log change in the consumer price index. Lack of corruption is an index of freedom from corruption.

\begin{tabular}{|c|c|c|c|c|c|c|}
\hline & $\begin{array}{c}\text { Demographic } \\
\text { branch } \\
\text { penetration }\end{array}$ & $\begin{array}{l}\text { Demographic } \\
\text { branch } \\
\text { penetration }\end{array}$ & $\begin{array}{l}\text { Demographic } \\
\text { branch } \\
\text { penetration }\end{array}$ & $\begin{array}{l}\text { Geographic } \\
\text { branch } \\
\text { penetration }\end{array}$ & $\begin{array}{l}\text { Geographic } \\
\text { branch } \\
\text { penetration }\end{array}$ & $\begin{array}{l}\text { Geographic } \\
\text { branch } \\
\text { penetration }\end{array}$ \\
\hline GDP per capita & $\begin{array}{c}2.33 \\
{[4.72]^{* * *}}\end{array}$ & $\begin{array}{c}2.13 \\
{[4.89]^{* * *}}\end{array}$ & $\begin{array}{l}-1.28 \\
{[0.70]}\end{array}$ & $\begin{array}{l}-0.77 \\
{[0.52]}\end{array}$ & $\begin{array}{l}-0.17 \\
{[0.13]}\end{array}$ & $\begin{array}{l}-1.28 \\
{[0.70]}\end{array}$ \\
\hline Population density & $\begin{array}{c}0 \\
{[1.45]}\end{array}$ & $\begin{array}{c}0 \\
{[1.92]^{*}}\end{array}$ & $\begin{array}{c}0.02 \\
{[1.22]}\end{array}$ & $\begin{array}{c}0.02 \\
{[1.22]}\end{array}$ & $\begin{array}{c}0.02 \\
{[1.08]}\end{array}$ & $\begin{array}{c}0.02 \\
{[1.22]}\end{array}$ \\
\hline Foreign ownership & $\begin{array}{c}-5.34 \\
{[3.10]^{* * *}}\end{array}$ & $\begin{array}{c}-4.6 \\
{[2.92] * * *}\end{array}$ & $\begin{array}{c}-13.34 \\
{[2.38]^{* * *}}\end{array}$ & $\begin{array}{c}-12.99 \\
{[2.50]^{* *}}\end{array}$ & $\begin{array}{c}-15.14 \\
{[2.52]^{* * *}}\end{array}$ & $\begin{array}{c}-13.34 \\
{[2.38]^{* * *}}\end{array}$ \\
\hline Inflation & & $\begin{array}{c}0.67 \\
{[1.16]}\end{array}$ & & & $\begin{array}{c}-1.95 \\
{[1.73]^{*}}\end{array}$ & \\
\hline Lack of corruption & & & $\begin{array}{c}2.88 \\
{[1.13]}\end{array}$ & & & $\begin{array}{c}2.88 \\
{[1.13]}\end{array}$ \\
\hline Observations & 39 & 39 & 39 & 39 & 39 & 39 \\
\hline R-squared & 0.47 & 0.49 & 0.44 & 0.42 & 0.46 & 0.44 \\
\hline & $\begin{array}{l}\text { Loan } \\
\text { accounts per } \\
\text { capita }\end{array}$ & $\begin{array}{l}\text { Loan accounts } \\
\text { per capita }\end{array}$ & $\begin{array}{l}\text { Loan } \\
\text { accounts per } \\
\text { capita }\end{array}$ & $\begin{array}{c}\text { Deposit } \\
\text { accounts } \\
\text { per capita }\end{array}$ & $\begin{array}{c}\text { Deposit } \\
\text { accounts } \\
\text { per capita }\end{array}$ & $\begin{array}{c}\text { Deposit accounts } \\
\text { per capita }\end{array}$ \\
\hline GDP per capita & $\begin{array}{c}30.42 \\
{[1.91]^{*}}\end{array}$ & $\begin{array}{l}18.33 \\
{[1.43]}\end{array}$ & $\begin{array}{c}28.08 \\
{[2.00]^{*}}\end{array}$ & $\begin{array}{c}337.85 \\
{[4.06]^{* * *}}\end{array}$ & $\begin{array}{c}252.12 \\
{[2.96]^{* * *}}\end{array}$ & $\begin{array}{c}359.53 \\
{[3.01]^{* * *}}\end{array}$ \\
\hline Population density & $\begin{array}{c}0.02 \\
{[0.59]}\end{array}$ & $\begin{array}{c}0 \\
{[0.06]}\end{array}$ & $\begin{array}{c}0.03 \\
{[0.90]}\end{array}$ & $\begin{array}{l}-0.24 \\
{[1.38]}\end{array}$ & $\begin{array}{c}0 \\
{[0.02]}\end{array}$ & $\begin{array}{l}-0.24 \\
{[1.35]}\end{array}$ \\
\hline Foreign ownership & $\begin{array}{r}-91.42 \\
{[1.42]}\end{array}$ & $\begin{array}{c}-143.35 \\
{[1.68]}\end{array}$ & $\begin{array}{l}-77.83 \\
{[1.38]}\end{array}$ & $\begin{array}{c}-926.77 \\
{[3.12]^{* * *}}\end{array}$ & $\begin{array}{c}-601 \\
{[2.52]^{* *}}\end{array}$ & $\begin{array}{c}-892.7 \\
{[3.23]^{* * *}}\end{array}$ \\
\hline Inflation & & & $\begin{array}{c}7.56 \\
{[0.52]}\end{array}$ & & $\begin{array}{c}193.54 \\
{[2.35]^{* *}}\end{array}$ & \\
\hline Corruption & & $\begin{array}{l}57.67 \\
{[1.44]}\end{array}$ & & & & $\begin{array}{l}-106.8 \\
{[0.41]}\end{array}$ \\
\hline Observations & 18 & 18 & 18 & 24 & 24 & 24 \\
\hline R-squared & 0.32 & 0.41 & 0.33 & 0.58 & 0.68 & 0.58 \\
\hline
\end{tabular}




\section{Table 11. Private Credit and Foreign Bank Presence: OLS Regressions Including All Countries}

This table reports the results of cross-sectional OLS regressions for all the countries for which data are available. The dependent variable is the ratio of bank credit to the private sector to GDP. GDP per capita is GDP in U.S. dollars divided by population. Foreign ownership is the ratio of bank assets in banks controlled by foreigners to total bank assets in the country. Transition is a dummy variable for formerly centrally planned economies. Inflation is the log difference in the consumer price index. Lack of corruption is an index measuring the freedom from corruption. Creditor information measures the cost to banks of obtaining information about borrowers. Enforcement speed is the inverse of the number of days it takes to enforce a basic business contract. State banks is the share of bank assets in state-owned banks.

\section{Private Credit}

Low-Income and Lower-MiddleIncome
All Countries
High-Income and Upper-MiddleIncome

\begin{tabular}{lccc}
\hline GDP per capita & 5.65 & 5.84 & 22.33 \\
Foreign ownership & {$[3.40]^{* * *}$} & {$[2.32]^{* *}$} & {$[1.49]$} \\
& $\mathbf{- 1 8 . 8 8}$ & $\mathbf{- 3 . 9 8}$ & $\mathbf{2 4 . 4 6}$ \\
Transition & {$[\mathbf{3 . 0 9}]^{* * *}$} & {$[\mathbf{0 . 3 2}]$} & {$[\mathbf{0 . 7 6}]$} \\
& -5.2 & -4.8 & 1.65 \\
Inflation & {$[1.34]$} & {$[1.04]$} & {$[0.14]$} \\
& -5.76 & -5.56 & -3.94 \\
Lack of corruption & {$[4.13]^{* * *}$} & {$[2.30]^{* *}$} & {$[0.57]$} \\
& 8.45 & 12.23 & 5.45 \\
Creditor information & {$[2.00]^{*}$} & {$[2.50]^{* *}$} & {$[0.60]$} \\
& 1.48 & 1.96 & 3.79 \\
Enforcement speed & {$[2.34]^{* *}$} & {$[1.58]$} & {$[1.14]$} \\
& 423.6 & 724.48 & 351.28 \\
State banks & {$[2.78]^{* * *}$} & {$[1.65]$} & {$[0.31]$} \\
& & & \\
Observations & & & 102 \\
R-squared & 59 & 0.71 & 0.55 \\
Robust $t$ statistics in brackets & 0.63 & & \\
$*$ significant at $10 \% ; *$ significant at $5 \% ; * * *$ significant at $1 \%$ & & \\
\hline
\end{tabular}




\section{Figure 1}

\section{Impact of Foreign Bank Entry on Welfare and Aggregate Lending}

This figure describes how aggregate welfare evolves as a function of the monitoring cost $c_{H}$, and summarizes the effect on aggregate lending of a switch away from the pooling equilibrium. In the pooling equilibrium, welfare does not depend on $c_{H}$ since all agents are pooled together and no monitoring costs are paid. In the other equilibria, the welfare function increases linearly with $c_{H}$.
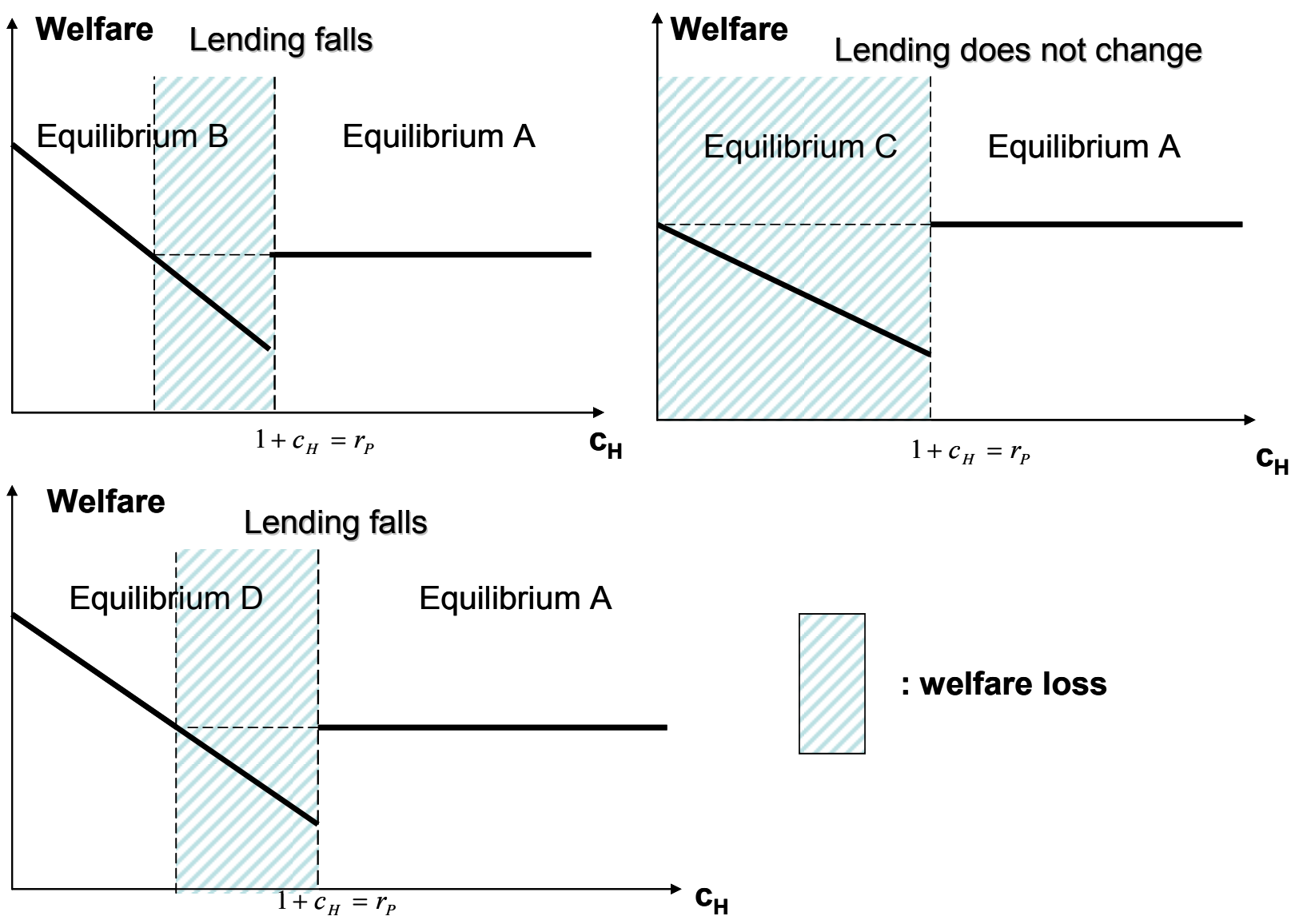

\section{: welfare loss}


Figure 2. Bank Credit to the Private Sector in Lower Income Countries by Region (Percent of GDP)

Sub-Saharan Africa

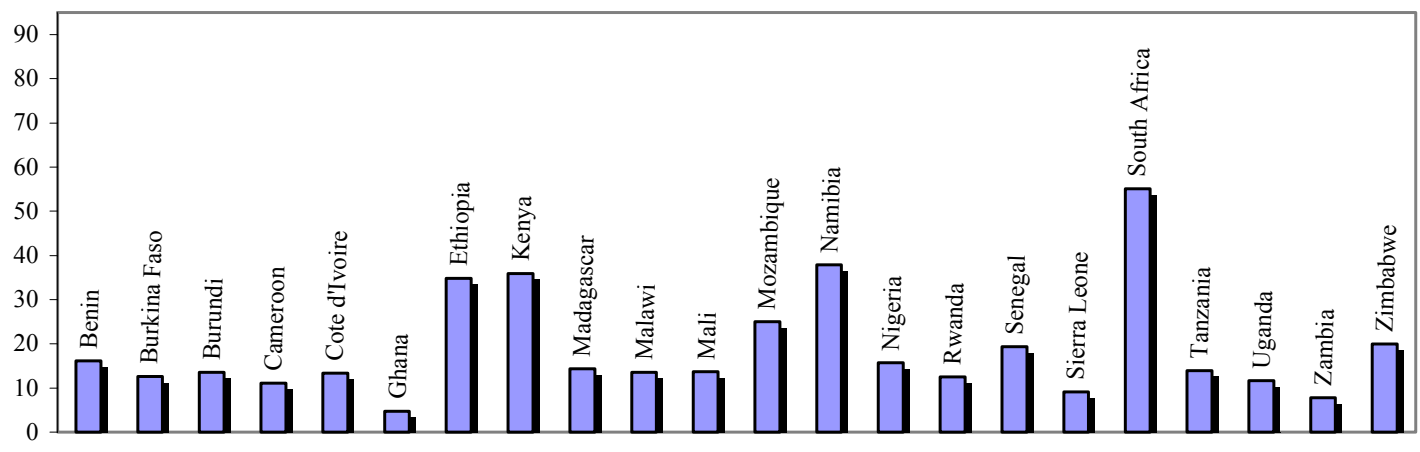

Latin America

Middle East and North Africa
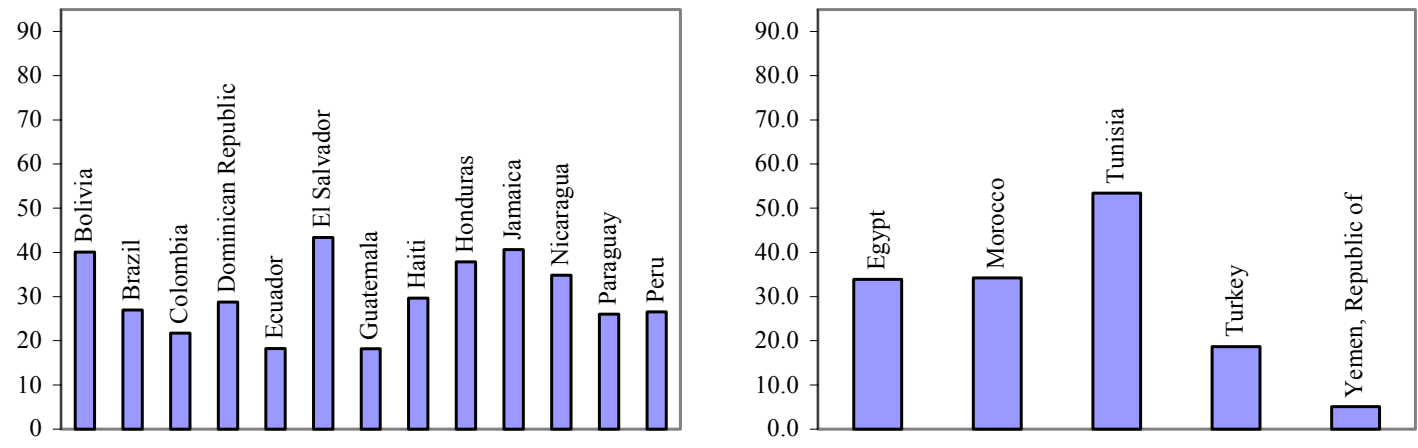

Europe and Central Asia

South and East Asia
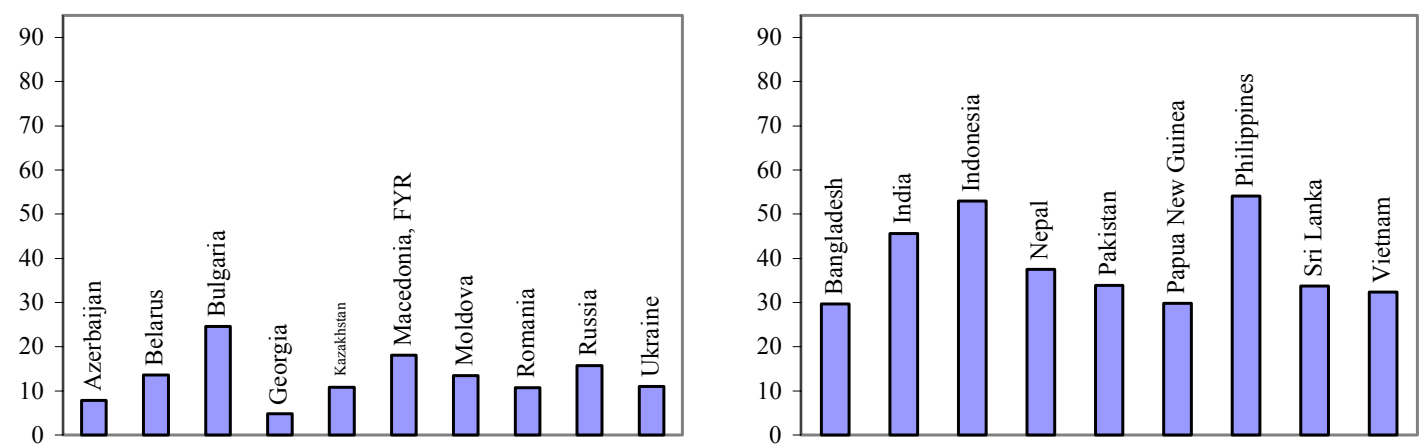

Source: IMF, International Financial Statistics. 
Figure 3. Foreign Bank Presence by Region in Selected Lower Income Countries

Sub-Saharan Africa

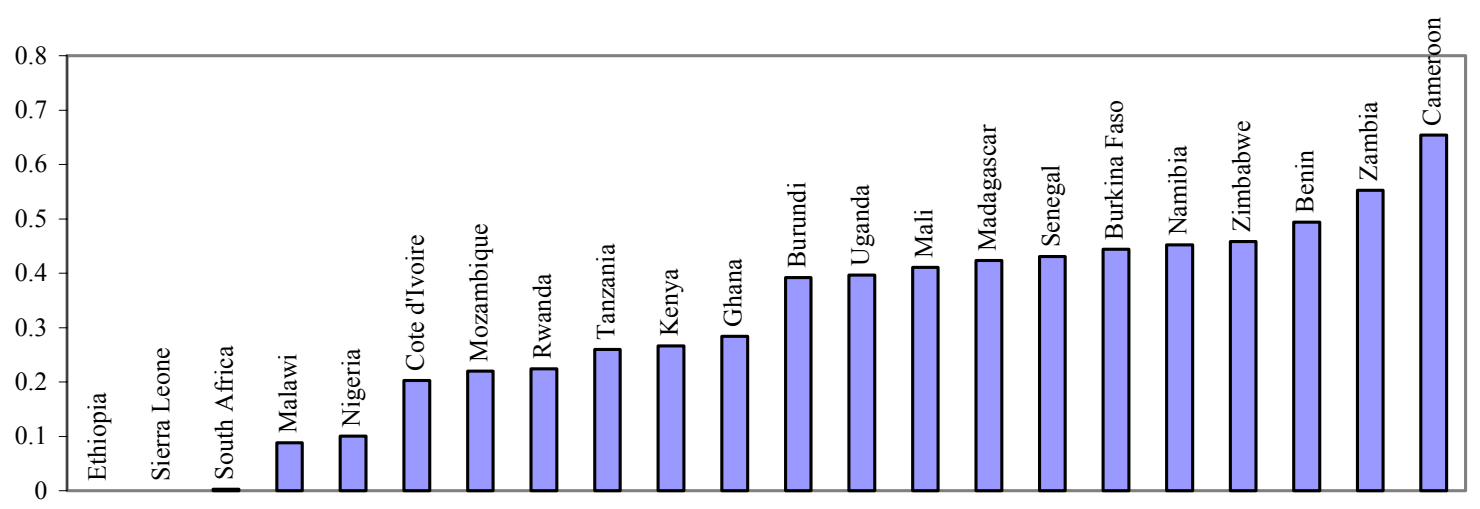

Latin America and Caribbean

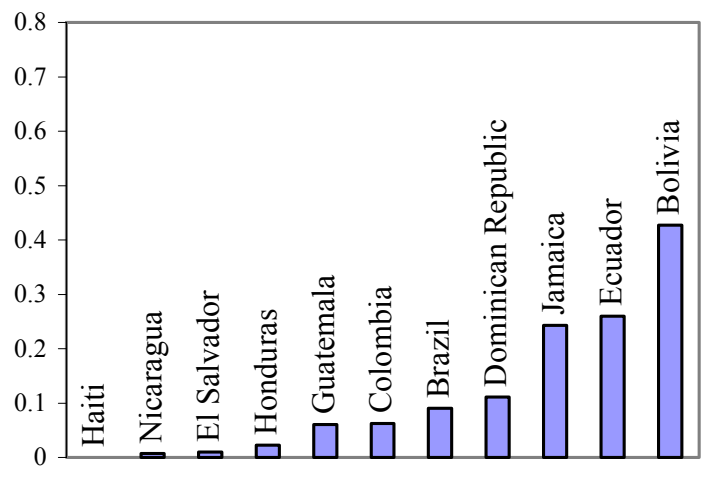

Europe and Central Asia

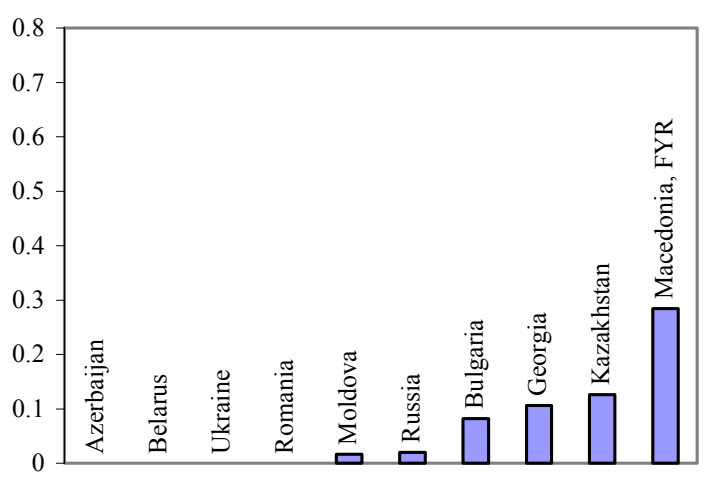

Middle-East and North Africa

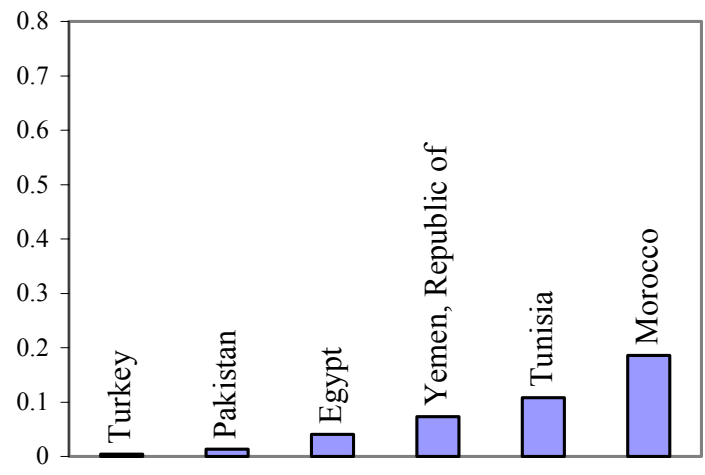

South and East Asia

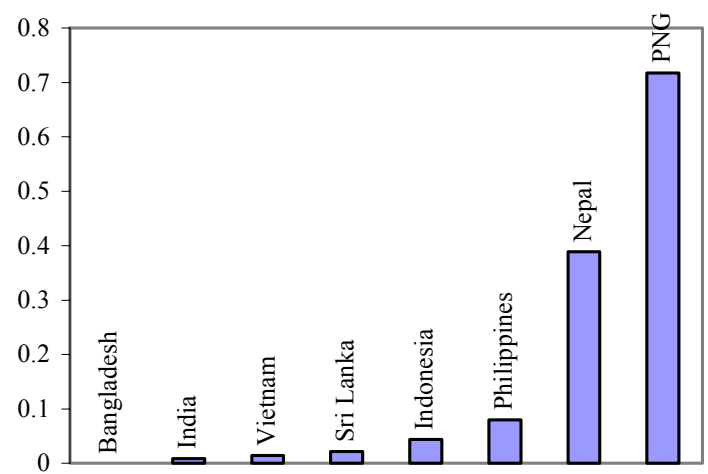

Source: Micco, Panizza, and Yanez (2004). 
Figure 4. Private Credit to GDP and Foreign Bank Presence

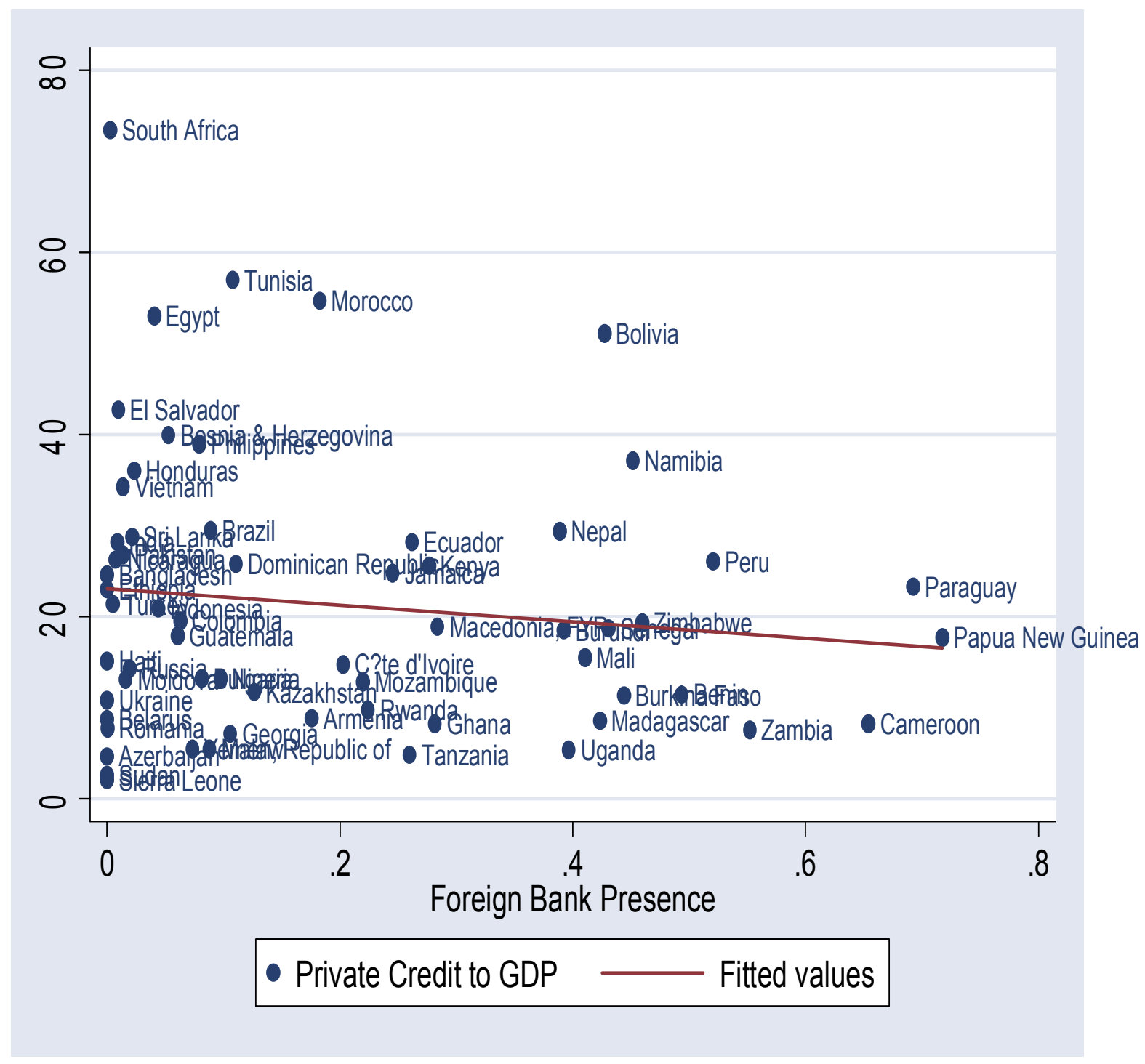


Figure 5

Change in Private Credit to GDP and Change in Foreign Bank Presence (1995-2002)

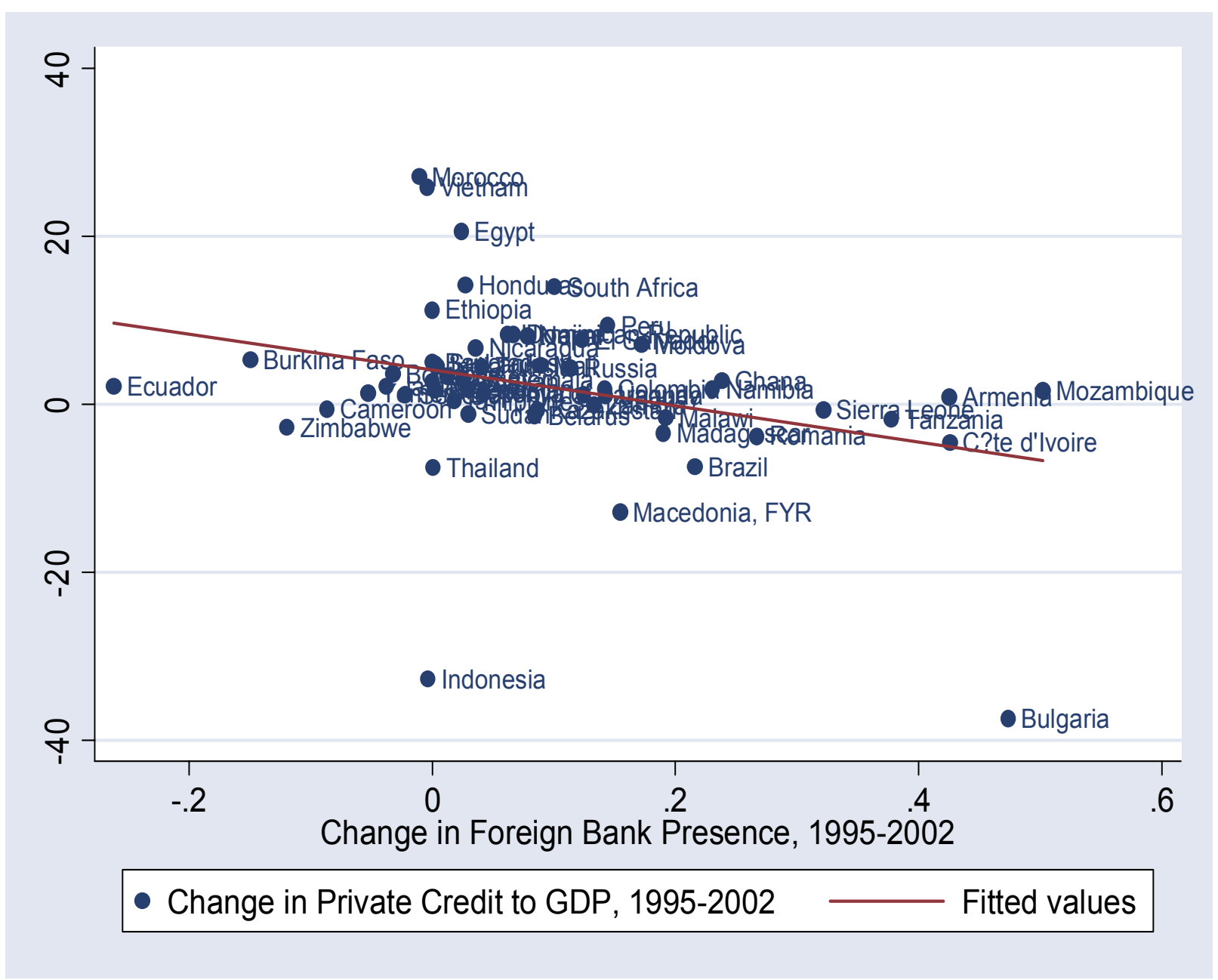




\section{Appendix 1. Welfare Comparison Under Alternative Equilibria}

The welfare attained in each of the possible equilibria is the following:

1. Pooling equilibrium (A): $S_{(A)}=\left(\mu_{H}+\mu_{S}+p \mu_{B}\right) \cdot R-1$

2. Separating equilibrium (B): $S_{(B)}=\left(\mu_{H}+\mu_{S}\right) \cdot R-\mu_{H} \cdot\left(1+c_{H}\right)-\mu_{S} \cdot\left(1+c_{S}\right)$

3. semi-separating equilibrium (C): $S_{(C)}=\left(\mu_{H}+\mu_{S}+p \mu_{B}\right) \cdot R-1-c_{H} \mu_{H}$

4. Credit-constrained equilibrium (D): $S_{(D)}=\mu_{H} \cdot\left(R-\left(1+c_{H}\right)\right)$

Comparison of welfare in equilibria $(A)$ and $(B)$ :

The difference between expected net output in the separating and pooling equilibrium is $S_{(B)}-S_{(A)}=\underbrace{\mu_{B} \cdot(1-p R)}_{>0} \underbrace{-\mu_{H} c_{H}-\mu_{S} c_{S}}_{<0}$. The first term is the welfare gain from not financing type $B$ anymore; the second term is the welfare cost of monitoring soft and hard information. The overall effect is ambiguous. Notice, however, that when $c_{H}+1=r_{P}$, the welfare in the separating equilibrium is unambiguously lower (see also Figure 1, panel 1):

$$
\left.S_{(B)}\right|_{1+c_{H}=r_{P}}-S_{(A)}=\Delta S_{(B)}=\underbrace{\frac{p \mu_{B}}{\mu_{H}+\mu_{S}+p \mu_{B}}-p \mu_{B} \cdot R}_{<0} \underbrace{-\mu_{S}\left(c_{S}-c_{H}\right)}_{<0}
$$

Where the first term is negative because $R>r_{P}=\frac{1}{\mu_{H}+\mu_{S}+p \mu_{B}}$.

Comparison of welfare in equilibria $(A)$ and $(C)$ : The comparison is straightforward: $S_{(C)}-S_{(A)}=\Delta S_{(C)}=-\mu_{H} c_{H} \leq 0:$ welfare falls because all projects are financed, but monitoring costs are paid in equilibrium.

Comparison of welfare in equilibria $(A)$ and $(D)$ : One can show that, for 


$$
c_{H}+1=r_{P}:\left.S_{(D)}\right|_{c_{H}+1=r_{P}}-S_{(A)}=\Delta S_{(D)}=-\left(\mu_{S}+p \mu_{B}\right) \cdot\left(R-r_{P}\right)<S_{(A)}
$$

And for $c_{H}=0,\left.S_{(D)}\right|_{c_{H}=0}=S_{(A)}-\left(\mu_{S}+p \mu_{B}\right) \cdot\left(R-\hat{r}_{P}\right)>S_{(A)}$ where $\hat{r}_{P}$ is the interest rate charged by banks pooling type $S$ and type $B$ together, because in this case the interest rate pooling types $(B)$ and $(A)$ is too high to sustain such as pooling equilibrium $\left(\hat{r}_{P}>R\right)$.

Comparison of welfare in equilibria $(B)$ and $(C)$ :

This comparison shows that welfare in the separating equilibrium is always higher than welfare in the semi-pooling equilibrium whenever the separating equilibrium is feasible.

$$
\begin{aligned}
& S_{(B)}-S_{(C)}=-p \mu_{B} R-\mu_{S} \cdot\left(1+c_{S}\right)+\left(\mu_{S}+\mu_{B}\right), \text { hence: } \\
& S_{(B)}-S_{(C)}>0 \Leftrightarrow 1+c_{S}<\frac{\mu_{S}+\mu_{B}(1-p R)}{\mu_{S}}
\end{aligned}
$$

As shown in the comparison between $S_{(B)}$ and $S_{(A)}$, this always holds. 


\section{Appendix 2}

\section{Table A1. Data Sources for Country Level Data}

\begin{tabular}{|c|c|c|}
\hline Country-Level Variables & Time period & Data sources \\
\hline GDP per capita $(\operatorname{logs})$ & $1991-98$ & World Bank, WDI \\
\hline Inflation (in logs) & $1991-98$ & IMF-IFS \\
\hline Lack of corruption & & Kaufmann et al. (2003) \\
\hline Days to enforce a contract & 2004 & World Bank; Doing Business database \\
\hline \multirow[t]{2}{*}{ Credit information index } & 2004 & World Bank; Doing Business database \\
\hline & Average & \\
\hline \multirow[t]{2}{*}{ State-Owned Bank Assets } & $1995-98$ & Micco et al. (2004) \\
\hline & Average & \\
\hline French legal origin (dummy) & & La Porta et al. (2002) \\
\hline Settlers' mortality & & Acemoglu et al. (2001) \\
\hline Official European language & 2003 & CEPII (2006). \\
\hline Foreign assets and liabilities & $1991-98$ & Lane and Milesi-Ferretti (2006) \\
\hline Banking crises & $1980-2002$ & Demirgüç-Kunt and Detragiache (2005) \\
\hline Mortality rate & $1990-2002$ & World Bank-WDI \\
\hline & Average & \\
\hline Population & $1995-98$ & World Bank-WDI \\
\hline Share of international banks from colonizer & 2002 & Cerutti, Dell'Ariccia, and Martinez Peria (2005) \\
\hline
\end{tabular}


Table A2

Bank Level Variables -Definitions

\section{Variable name}

Loan-loss provisioning / net interest revenue

Net loans / total assets

Size

Foreign

State-owned

Capitalization

ROAA

Overheads

Source: Bankscope database.

\section{Time} period Definition

$1995-$

$2003 \log (1+$ loan loss provisioning / net interest revenue $)$

$1995-$

2003

$1995-$

2003

$1995-$

2003

$1995-$

2003

$1995-$

2003

$1995-$

2003

1995

2003 $\log (1+$ net loans / total assets $)$

$\log$ ( total assets )/GDP

dummy equal to one if a foreign owner holds more than 50 percent of shares

dummy equal to one if the state holds more than 50

percent of shares

$\log (1+$ equity / total assets $)$

$\log (1+$ return over average assets $)$

Overheads costs / total assets 


\section{Appendix 3}

\section{Model Simulation}

In this appendix, it will be shown that for reasonable values of the parameters the theoretical model can generate a relationship between foreign bank penetration and the ratio of credit to GDP in line with that found in the baseline regression. Specifically, the estimated coefficient of the baseline cross-sectional regression implied that an increase in foreign bank penetration by one standard deviation ( 20 percentage points) would lead to a reduction of the ratio of private credit to GDP of 6 percentage points.

Assuming that at the sample average the country is in a semi-pooling equilibrium and that the increase in foreign bank penetration is associated to a change to the separating equilibrium, then using the parameter assumptions in the table below and the formulas from Table 1, we obtain that a 19 percentage points increase in the foreign share is associate with a decline in 6.5 percentage points in credit to the private sector. This is quite close to the magnitude implied by the cross-country baseline regression.

\begin{tabular}{|l|l|l|}
\hline & Symbol & Value assumed in simulation \\
\hline Share of soft information borrowers & $\mu_{S}$ & 0.60 \\
\hline Share of hard information borrowers & $\mu_{H}$ & 0.24 \\
\hline Gross return on investment & $R$ & 1.20 \\
\hline Probability of success of bad project & $p$ & 0.55 \\
\hline
\end{tabular}

